\title{
Adverse effects in hematologic malignancies treated with chimeric antigen receptor (CAR) T cell therapy: a systematic review and Meta- analysis
}

Wenjing Luo ${ }^{1,2}$, Chenggong Li ${ }^{1,2}$, Yinqiang Zhang ${ }^{1,2}$, Mengyi Du ${ }^{1,2}$, Haiming Kou ${ }^{1,2}$, Cong Lu ${ }^{1,2}$, Heng $\mathrm{Mei}^{1,2^{*}}$ (D) and $\mathrm{Yu} \mathrm{Hu} u^{1,2^{*}}$

\begin{abstract}
Background: Recently, chimeric antigen receptor-modified (CAR) T cell therapy for hematological malignancies has shown clinical efficacy. Hundreds of clinical trials have been registered and lots of studies have shown hematologic toxic effects were very common. The main purpose of this review is to systematically analyze hematologic toxicity in hematologic malignancies treated with CAR-T cell therapy.

Methods: We searched databases including PubMed, Web of Science, Embase and Cochrane up to January 2021. For safety analysis of overall hematologic toxicity, the rate of neutrophil, thrombocytopenia and anemia were calculated. Subgroup analysis was performed for age, pathological type, target antigen, co-stimulatory molecule, history of hematopoietic stem cell transplantation (HSCT) and prior therapy lines. The incidence rate of aspartate transferase (AST) increased, alanine transaminase (ALT) increased, serum creatine increased, APTT prolonged and fibrinogen decreased were also calculated.

Results: Overall, 52 studies involving 2004 patients were included in this meta-analysis. The incidence of any grade neutropenia, thrombocytopenia and anemia was 80\% (95\% Cl: 68-89\%), 61\% (95\% Cl: 49-73\%), and 68\% (95\%Cl: 54-80\%) respectively. The incidences of grade $\geq 3$ neutropenia, thrombocytopenia and anemia were $60 \%(95 \% \mathrm{Cl}$ : 49-70\%), 33\% (95\% Cl: 27-40\%), and 32\% (95\%Cl: 25-40\%) respectively. According to subgroup analysis and the corresponding $Z$ test, hematological toxicity was more frequent in younger patients, in patients with $\geq 4$ median lines of prior therapy and in anti-CD19 cases. The subgroup analysis of CD19 CAR-T cell constructs showed that 41BB resulted in less hematological toxicity than CD28.
\end{abstract}

Conclusion: CAR-T cell therapy has dramatical efficacy in hematological malignancies, but the relevant adverse effects remain its obstacle. The most common $\geq 3$ grade side effect is hematological toxicity, and some cases die from infections or severe hemorrhage in early period. In long-term follow-up, hematological toxicity is less life-threatening generally and most suffered patients recover to adequate levels after 3 months. To prevent life-threatening infections or bleeding events, clinicians should pay attention to intervention of hematological toxicity in the early process of CAR-T cell therapy.

\footnotetext{
*Correspondence: hmei@hust.edu.cn; dr_huyu@126.com

${ }^{1}$ Institute of Hematology, Union Hospital, Tongji Medical College,

Huazhong University of Science and Technology, 430022 Wuhan, China

Full list of author information is available at the end of the article
}

(C) The Author(s) 2022. Open Access This article is licensed under a Creative Commons Attribution 4.0 International License, which permits use, sharing, adaptation, distribution and reproduction in any medium or format, as long as you give appropriate credit to the original author(s) and the source, provide a link to the Creative Commons licence, and indicate if changes were made. The images or other third party material in this article are included in the article's Creative Commons licence, unless indicated otherwise in a credit line to the material. If material is not included in the article's Creative Commons licence and your intended use is not permitted by statutory regulation or exceeds the permitted use, you will need to obtain permission directly from the copyright holder. To view a copy of this licence, visit http://creativecommons.org/licenses/by/4.0/. The Creative Commons Public Domain Dedication waiver (http://creativeco mmons.org/publicdomain/zero/1.0/) applies to the data made available in this article, unless otherwise stated in a credit line to the data. 
Keywords: Chimeric antigen receptor, Hematological malignancies, Hematologic toxicity, Meta-analysis, Review

\section{Background}

Hematological malignancies accounted for 1.2 million, that was around $7 \%$, newly diagnosed cancer cases every year worldwide [1]. Among them, lymphocytic leukemia, lymphoma and multiple myeloma (MM) represent a large part. Chemotherapy, as a traditional and common treatment for them, is being replaced gradually by some novel therapies, like chimeric antigen receptor-modified (CART) cell therapy.

CAR-T cells are produced strictly ex-vivo and then infused to patients by intravenous injection. The CARs, recognizing their targets by a specific mechanism distinct from classic TCRs, are comprised of an antigen-specific single-chain variable fragment $(\mathrm{scFv})$ that is fused to an internal T-cell signaling domain and costimulatory molecules like CD28 or 41BB [2]. The development of CAR-T cell therapy was a wave of optimism for selected hematological malignancies in the past decades. Meanwhile, cytokine release triggered by CAR-T cell activation, expansion and cytotoxicity, leads to CRS, immune effector cell-associated neurotoxicity syndrome (ICANS) and even hematological toxicities [3, 4]. Adverse effects related to CAR-T cell therapy should be paid attention to, and there are already some reviews reporting the overall rate of CRS and ICANS. And hematological toxicity is the most common grade $\geq 3 \mathrm{AE}$ in CAR-T cell therapy [5]. Given that hepatotoxicity, nephrotoxicity and coagulation disorders are not rare in the treatment of hematological malignancies, we analyzed these incidences as the secondary outcome. The analysis of the landscape of hematological toxic effects associated with CAR-T cell therapy seems to be extremely significant.

We searched databases including PubMed and Web of Science to explore the adverse effects during the CAR-T cell therapy, and 52 studies involving 2004 patients were included in this meta-analysis. We mainly analyzed hematological toxicity, and we also conducted subgroup analysis. We aimed to provide some references for CAR-T cell therapy and draw clinicians' attention to AEs associated with CAR-T cell therapy, besides CRS and neurotoxicity.

\section{Materials and methods}

This study is registered in International Prospective Register of Systematic Reviews (PROSPERO) and the number is CRD 42021237114. We did our meta-analysis and systematic review in accordance with the PRISMA (Preferred Reporting Items for Systematic Reviews and
Meta-Analyses) guidelines [6] and the checklist is shown in Supplementary Material.

\section{Search strategy}

We searched PubMed, Web of Science, Embase and Cochrane up to January 2021, and the terms for the literature search were "chimeric antigen receptor", "CAR$\mathrm{T}$, "chimeric antigen receptor-modified $\mathrm{T}$ cell therapy", "blood system toxicity", "hematopoietic system toxicity", "hematological toxicity", "adverse effects", "side effects", "leukemia", "multiple myeloma", "lymphoma" and "hematological malignancies". To guarantee comprehensive search and to include all potentially relevant studies, we examined related meta-analysis and cross-referenced the references of identified articles. The search results were imported in Endnote X9 and duplicates were identified and removed through Endnote X9 and manually. Two independent researchers (Luo WJ and Mei $\mathrm{H}$ ) screened retrieved documents and assessed independently full texts of articles on the basis of prespecified inclusion criteria. All disagreements were resolved by discussion with the third researcher $(\mathrm{Hu} \mathrm{Y})$.

\section{Selection criteria Inclusion criteria}

We included both articles published in journal and abstracts from conference proceedings, which reported the incidence rate of hematological toxicity in patients with CAR-T cell therapy. Both single-arm trials and retrospective studies were included. Case-series with detailed information of treatment and outcome were also included. We analyzed the most recently updated results of each included clinical trial, whether reported in published articles or conference proceedings.

\section{Exclusion criteria}

We excluded studies published in languages other than English and Chinese, and those focusing on the efficacy or safety of combinations of CAR-T cell therapy and other therapies. Studies with insufficient data where our aimed AEs were not reported, irrelevant studies, and studies with two or fewer patients were excluded. Studies with the same NCT number were screened, and we excluded these reports with the shorter follow-up. Meanwhile, clinical guidelines, consensus documents and systematic reviews were excluded from our meta-analysis. 


\section{Data extraction}

Two investigators independently reviewed and extracted the following information: study characteristics (first author, publication year, the number of included patients, ClinicalTrials.gov number, research design and the selected AEs criteria), patients characteristics (gender, age, pathological type, previous HSCT and prior therapy lines), intervention (pre-infusion conditioning, CAR-T cell dose, target selection and costimulatory molecule), the incidence rate (neutropenia, thrombocytopenia, anemia, AST increasement, ALT increasement, serum increasement, APTT prolongation and fibrinogenopenia), and the onset and recovery time of hematological toxicity. And we two stored the information using Microsoft Excel for analysis. Disagreements were settled by discussion with the third reviewer.

\section{Methodological quality of the included studies}

We used a specific tool for evaluating the methodological quality of the non-comparative studies [7]. This tool is categorized into four domains: selection of patients, ascertainment of exposure and outcome, causality and reporting [7]. We assessed methodological quality of each study by grading the risk of bias as low (score of 0-1), moderate (score of 2-3) and high (score of 4).

\section{Statistical analysis}

We used the "Meta" and "Metafor" packages in the R-4.0.3 statistical software to analyze therapeutic safety. The incidence rates and relevant 95\% confidence intervals (CIs) were calculated to estimate pooled results from studies. In case of no obvious heterogeneity $\left(\mathrm{I}^{2}<50 \%\right.$ and $P>0.05$ in the $\mathrm{Q}$ test), the results from fixed-effects model were reported in our meta-analysis. Otherwise, the results from random-effects model were reported. All pooled results with $P$-values $\leq 0.05$ were considered statistically significant. We performed the Egger's test to assess statistically the publication bias $(P>0.05$ was considered indicative of no significant publication bias), and funnel plots were constructed for providing a visual analysis of publication bias. Sensitivity analysis was conducted for estimating the effect on the overall rates of neutropenia, thrombocytopenia and anemia, with removal of the corresponding studies one by one. Subgroup analysis by age ( $<45$ vs. $\geq 45$ and $<60$ vs. $\geq 60)$, target antigen selected (CD19 vs. no CD19), co-stimulatory molecule (41BB vs. CD28), proportion of previous HSCT $(<50 \%$ vs. $\geq 50 \%)$, and the median lines of prior therapy $(<4$ vs. $\geq 4)$ was performed to explore the sources of heterogeneity, and $\mathrm{Z}$ test was conducted for comparing the merged incidence rates between subgroups.

\section{Results}

\section{Literature search and study characteristics}

Two thousand ninety potentially relevant studies were retrieved, and 356 studies were de-duplicated by EndNote X9. By screening titles and abstracts, 666 reviews, 51 case reports, 80 basic studies and 712 studies with irrelevant topic were excluded. After full texts were carefully reviewed, among studies based on the same data sources, we only included one with the most recent updated results of clinical trials. Besides, 132 studies with insufficient data were excluded. One additional study was included by cross searching the references of previous meta-analysis. Finally, 52 eligible studies involving 2004 patients were included [8-59]. The flowchart describing the literature selection process is presented in Fig. 1. The characteristics of the included studies is shown in Table 1 . Of the included studies, 47 (90\%) explored the incidence rate of hematological toxicity, 20 (38\%) explored the hepatic toxicity, 10 (19\%) explored the renal toxicity and 11 (21\%) explored the coagulation dysfunction related to CAR-T cell therapy. The detailed features of the included patients in their corresponding studies are presented in Table 2. As shown, the target patients of included studies were those with lymphoma, leukemia or MM. The proportion of male was 39-100\%; the median patients age ranged from 7.5 to 67 years; the median lines of prior therapy ranged from 3 to 7 ; and the proportion of prior HSCT was $0-100 \%$. Based on the assessment of quality, the included studies had a risk bias of low or moderate (Table 3).

\section{Hematological toxicity Overall incidence rate}

Forty-six studies $[8,10-16,18-25,27,28,30-32,34$, $35,37-52,54-56,58-61]$ reported the incidence rates of hematological toxicity. Of these, 40 studies [8, 10-12, 14-16, 18-28, 30, 32, 34, 35, 37-42, 44, 46-52, 55, 56, 58, 59] involving 1652 patients explored the rate of neutropenia, 41 [8-16, 18-28, 30-32, 34, 35, 37-46, 48, 49, 52, 54, 56, 59] studies involving 1619 patients explored the rate of thrombocytopenia, and $40[8-11,13,14,16,18-$ $25,27,28,30-32,35,37,39-47,49-52,54-56,58,59]$ studies involving 1638 patients explored the rate of anemia. As shown in Fig. 2, the total incidences of neutropenia, thrombocytopenia and anemia of any grades were 80\% (95\% CI: 68-89\%), 61\% (95\% CI: 49-73\%), and 68\% (95\%CI: 54-80\%) respectively. And the pooled results of grade $\geq 3$ neutropenia, thrombocytopenia and anemia were $60 \%$ (95\% CI: $49-70 \%), 33 \%$ (95\% CI: $27-40 \%)$, and $32 \%$ (95\%CI: $25-40 \%$ ) respectively. The pooled results are shown in Table 4 in detail. 


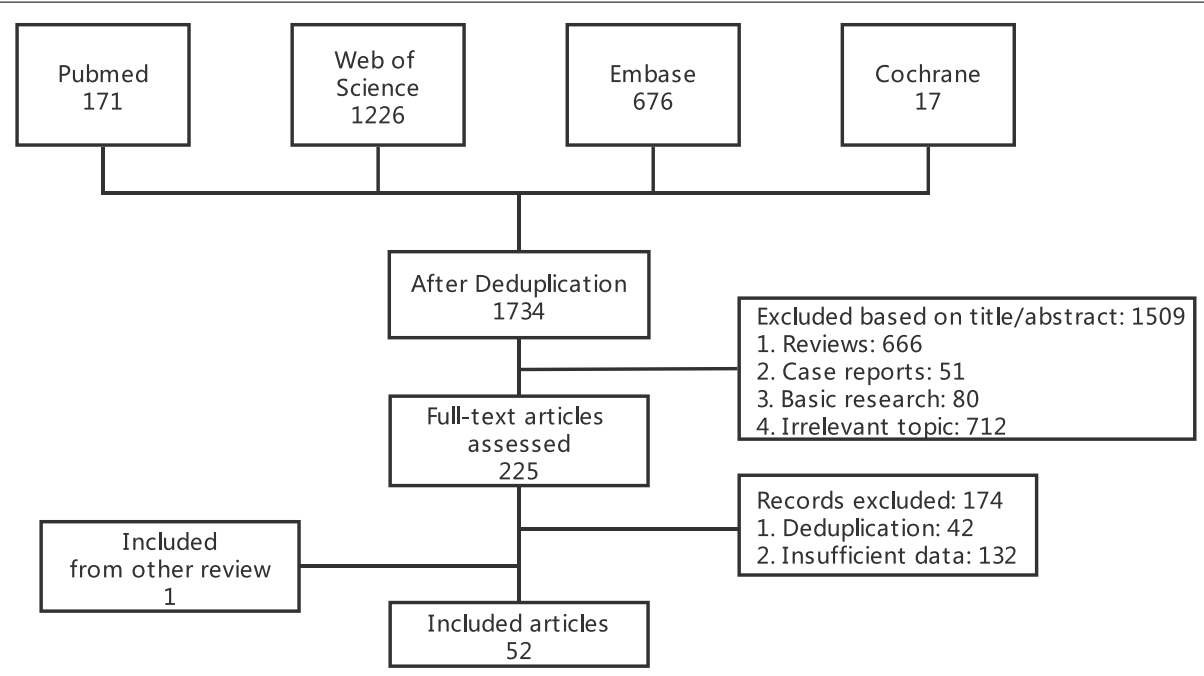

Fig. 1 Flowchart describing the literature selection process

\section{Subgroup analysis}

We performed subgroup analysis for age, pathological type, target antigen, co-stimulatory molecule, the proportion of previous HSCT and median lines of prior therapy.

We set the age into three groups as low ( $<45$ years old), middle ( $\geq 45$ and $<60$ years old) and high ( $\geq 60$ years old). The pooled results showed younger patients were more likely to experience hematological toxicity but with no statistical significance. According to pathological type, we analyzed the toxicity among patients with lymphoma, leukemia or MM and the result is presented in Tables 5 and 6. Subgroup analysis of target antigen (CD19 vs. no $\mathrm{CD} 19)$ revealed that non-CD19 cases had the higher rate of hematological toxicity. Especially in analyzing neutropenia, $\mathrm{Z}$ test illustrated that the difference between the two groups (CD19 vs. no CD19) was of statistical significance. For neutropenia of any grades, a higher rate of 93\% (95\% CI: 84-99\%) for non-CD19 studies compared with $73 \%$ (95\% CI: 58-86\%) for CD19 studies, and the $P$-value of the $\mathrm{Z}$ test was 0.0001 . Besides, the analysis of $\geq 3$ grade neutropenia showed that the incidences of nonCD19 cases and CD19 cases was 75\% (95\% CI: 57-90\%) and 52\% (95\% CI:40-64\%) respectively, and the P-value of the $\mathrm{Z}$ test was 0.0088 . The pooled result of proportion of previous HSCT $(<50 \%$ vs. $\geq 50 \%)$ was of no statistical significance. Therefore, the history of HSCT before CAR-T therapy does not have effect on hematological toxicity. Subgroup analysis by prior therapy lines showed that hematological toxicity was less frequent in the case of median lines $<4$ compared to $\geq 4$. However, the results were of no statistical significance, except in analysis of any grades thrombocytopenia. Additional details are shown in Tables 5 and 6.

For analyzing the effect of age on grade $\geq 3$ hematological toxicity in different pathological types, we conducted a subgroup analysis. Considering the distribution of age varying among different cancers, subgroups were set by different age. For studies focusing on lymphoma $(<60$ vs. $\geq 60$ years old), the patients with the age $<60$ were more likely to suffer hematological toxicity regularly. Especially, the pooled result of any grades anemia was of statistical significance and the $P$-value of the $\mathrm{Z}$ test was 0.0424 . Given that patients with leukemia were younger than lymphoma and MM overall from our extracted data, we set these patients into two group as $<20$ and $\geq 20$. The results revealed that the incidences of hematological toxicity were regularly higher in the older cases, and the $P$-value of $\mathrm{Z}$ test was 0.032 in any grades thrombocytopenia. For MM, because the studies were not adequate as lymphoma and leukemia, we only performed subgroup analysis by age ( $<60$ vs. $\geq 60$ years old) for grade $\geq 3$ hematological toxicity. The results showed that the hematological toxicity was more frequent in $\geq 60$ cases, and the $P$-values of $\mathrm{Z}$ test were statistically significant in grade $\geq 3$ neutropenia and thrombocytopenia $(0.0227$ and 0.0356 , respectively). The detailed results are shown in Tables 5 and 6.

Aiming to specifically analyze the effect of co-stimulatory molecule on hematological toxicity, we eliminated the confounding factor targeting antigen and chose the part with the most sufficient data. The selected studies focused on lymphoma patients treated with CAR-T cell targeting CD19, and we explored the different effects of co-stimulatory molecule (CD28 vs. $41 \mathrm{BB})$ with the 


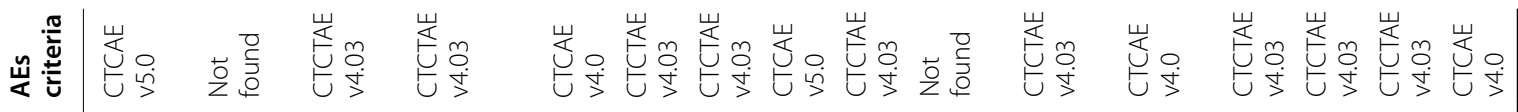
点, 星

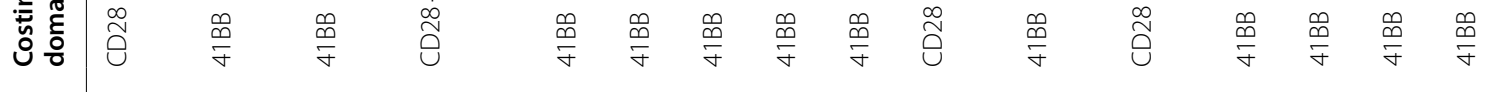

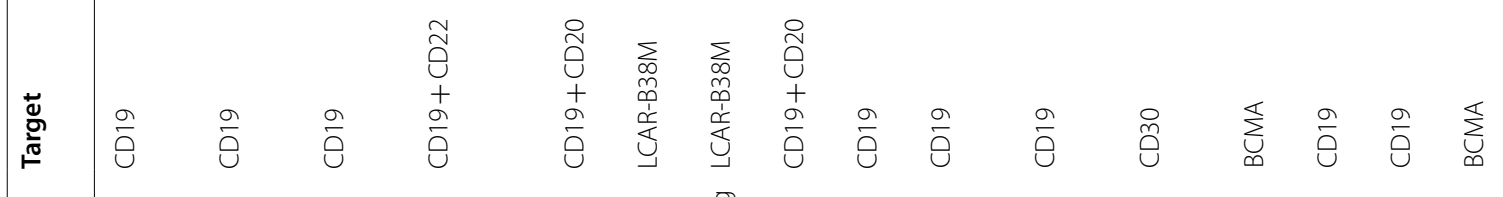

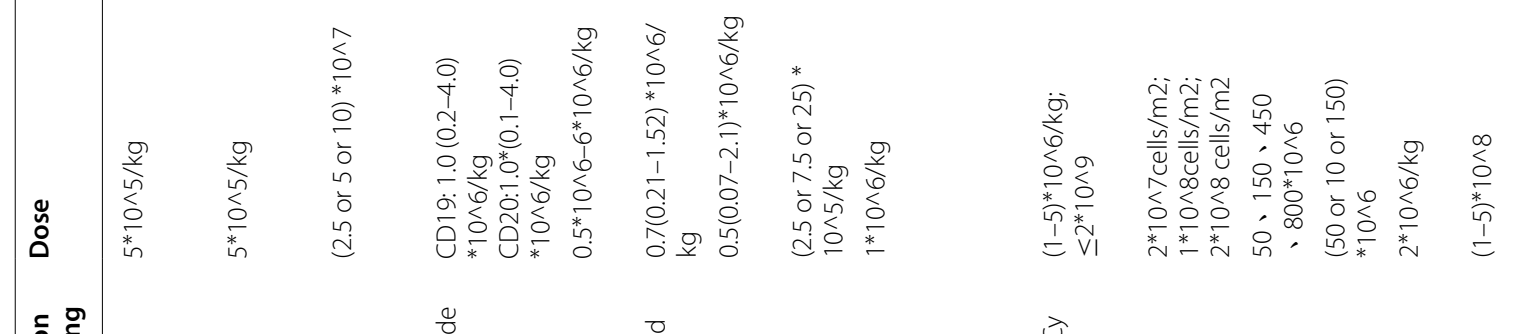
II

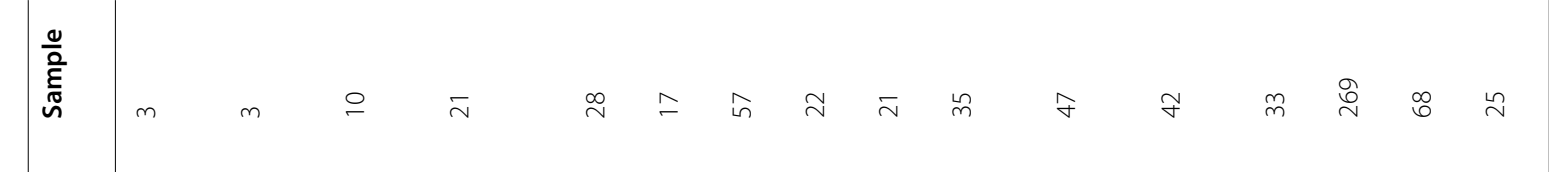

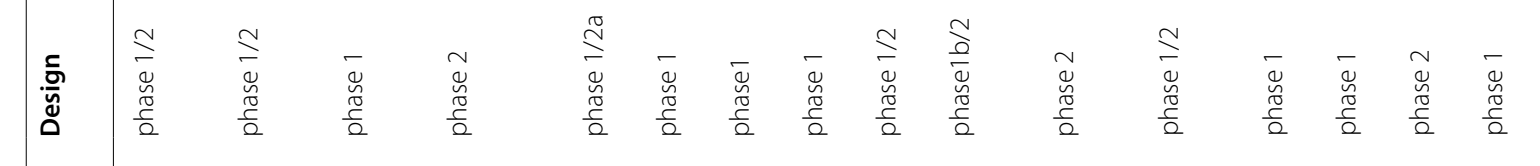

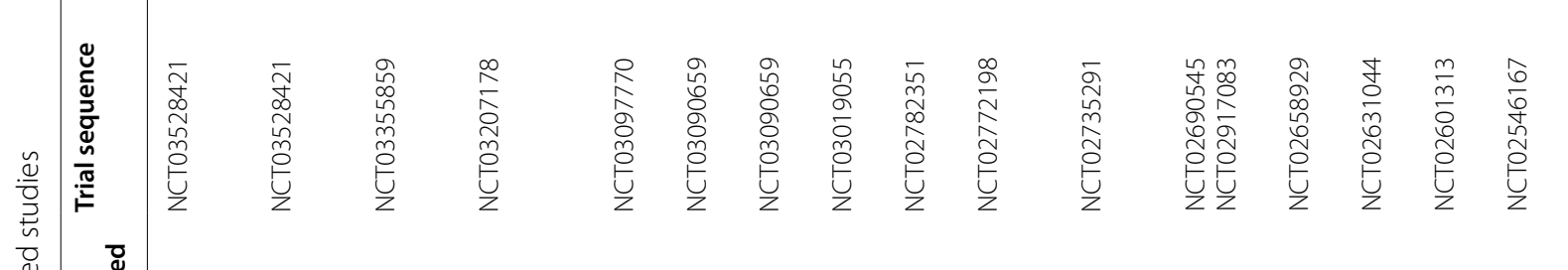

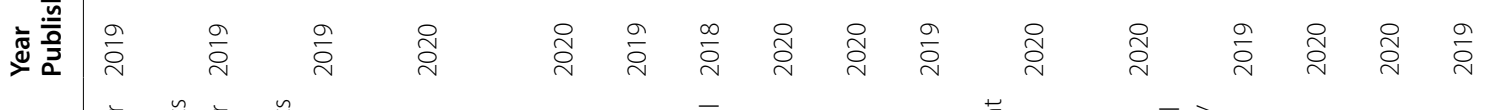

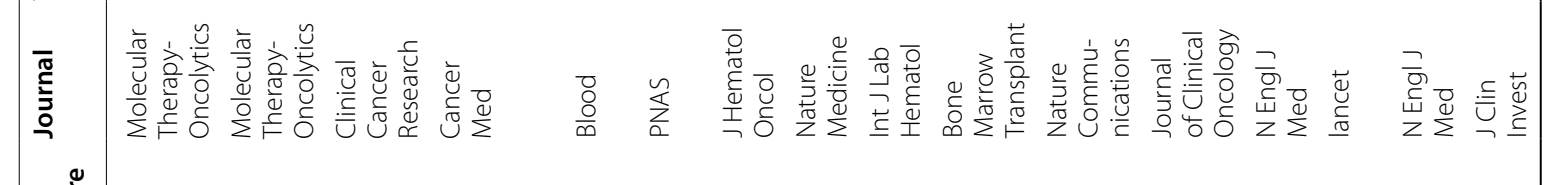

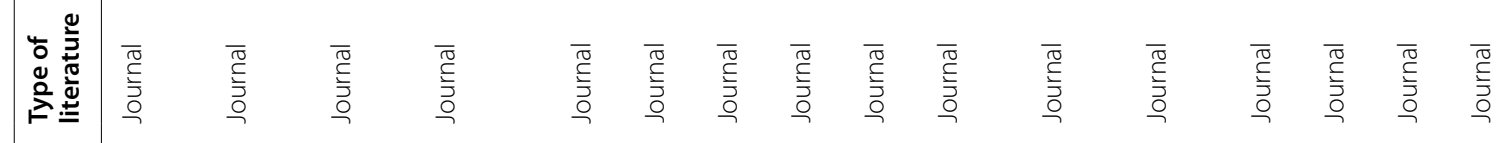




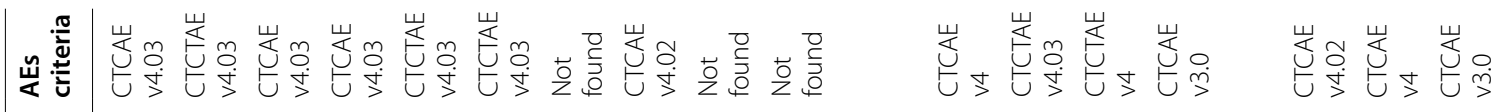

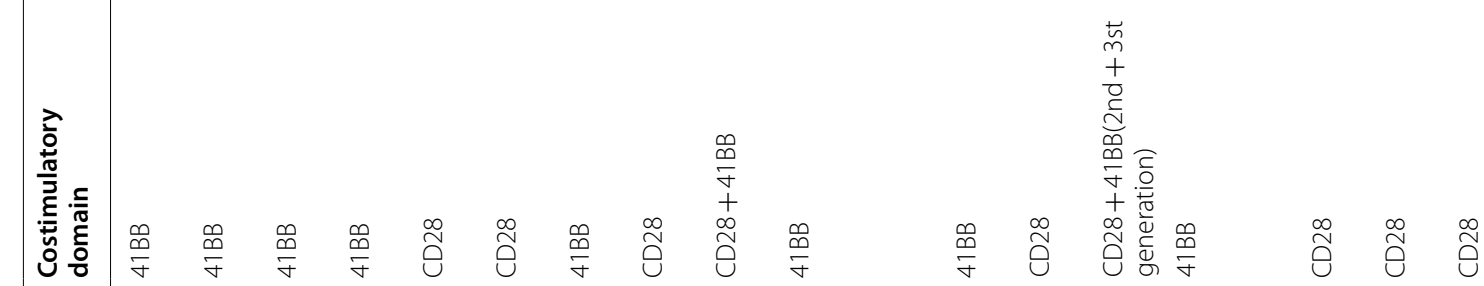

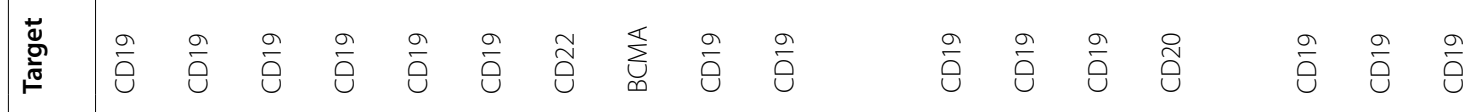

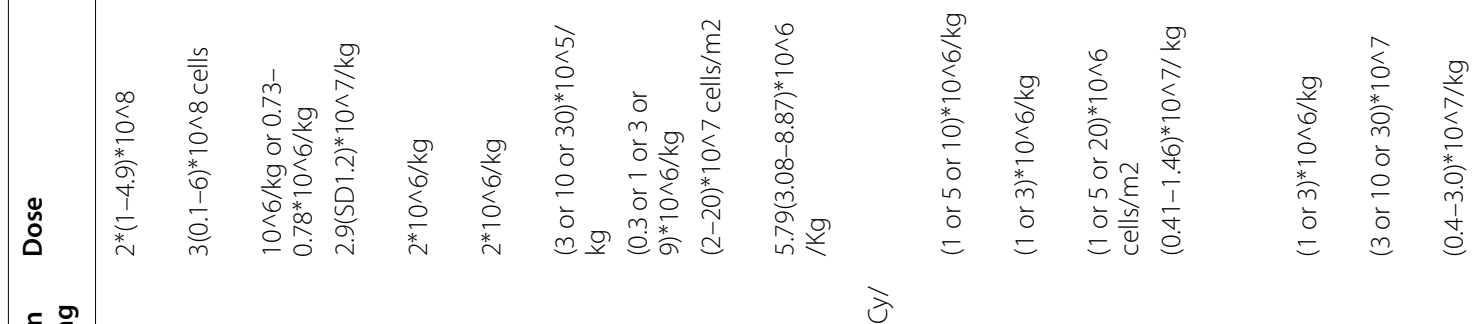

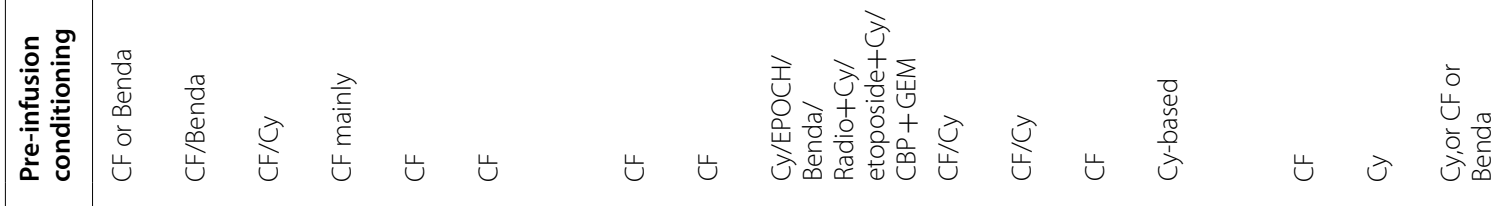
产

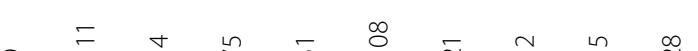

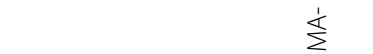

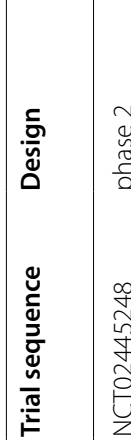
$\sum_{N}^{+}$

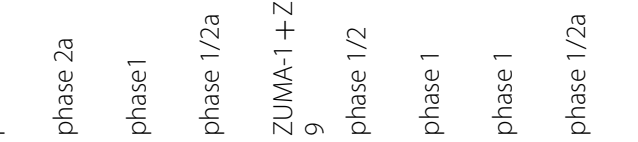

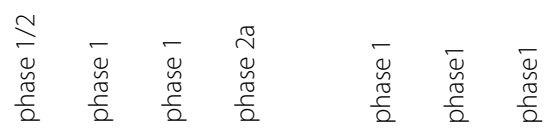




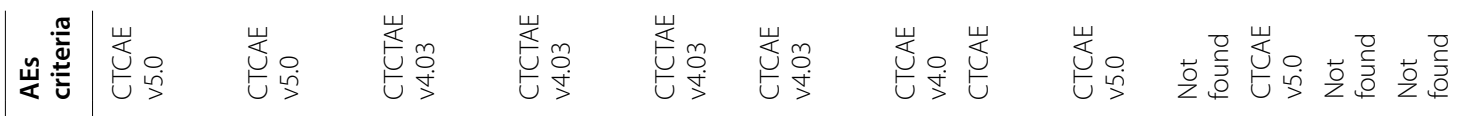<smiles>CC(C)C</smiles>

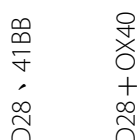

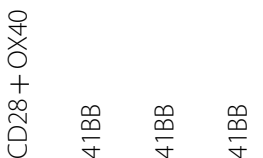

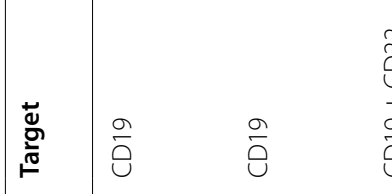<smiles>[B]=CCCC</smiles><smiles>[Si]=C1CCCCC1</smiles>

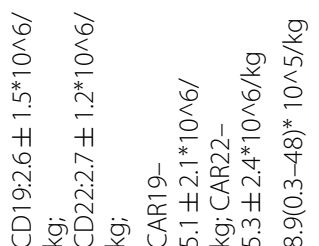
$\frac{2}{2}$

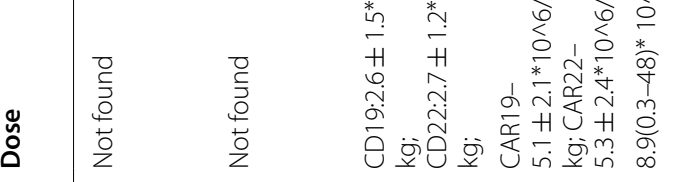

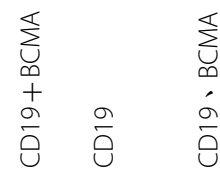

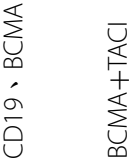
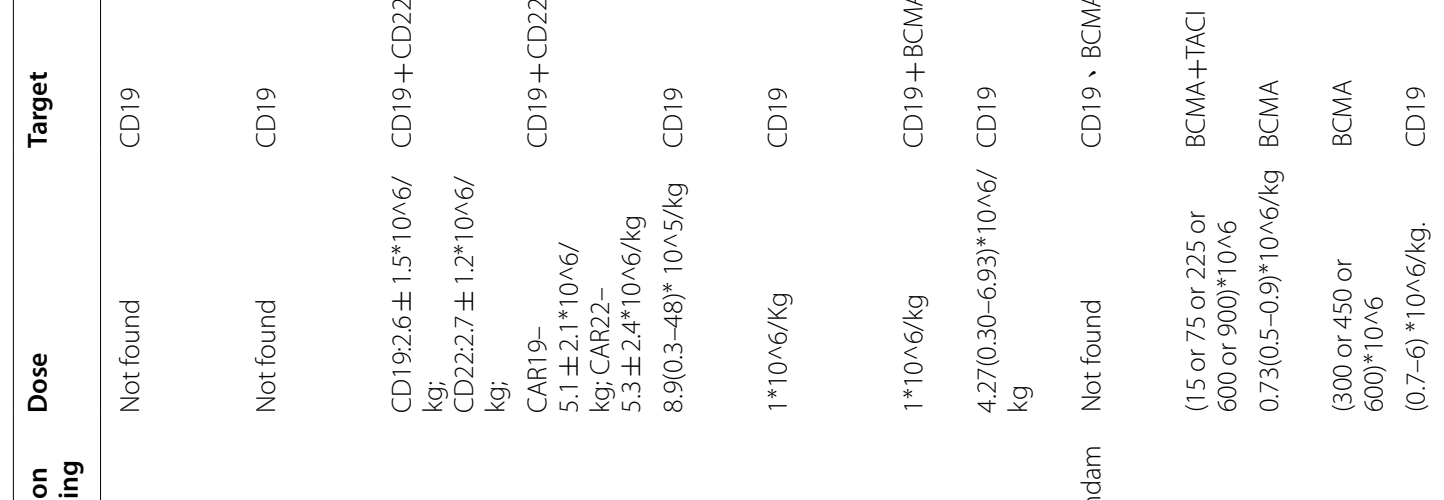

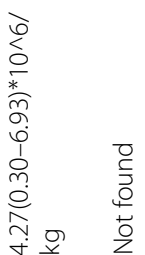

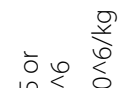

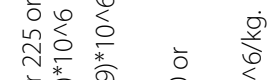

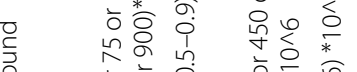

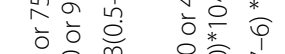

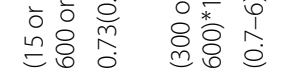

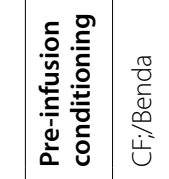

高

ڤn

录

ப 屶

岂岕

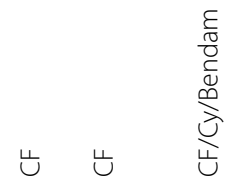

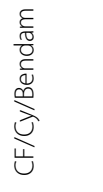<smiles>C1CC1</smiles>

(

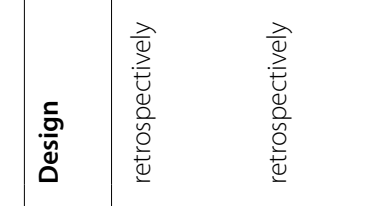

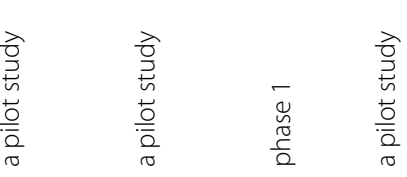

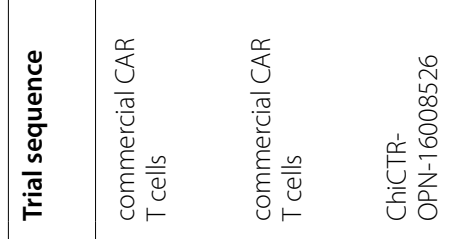

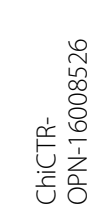

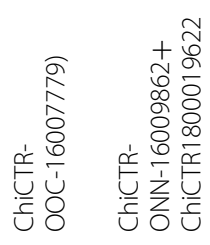

$\bar{\sim} \bigcirc$

ப $\sqcup$ ப

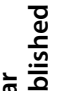

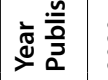

ठิ

$\stackrel{\circ}{\bar{\alpha}}$

ญั ญั

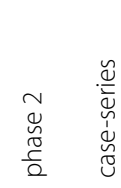

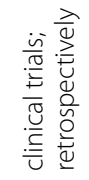

$=\stackrel{\sim}{\bar{n}} \infty$

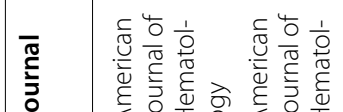

을

离

辛 을

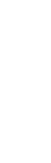

亨

$\frac{1}{2}$

高

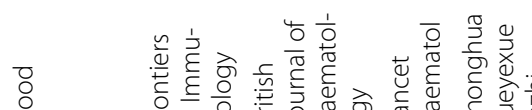

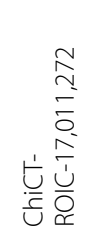

हुछ

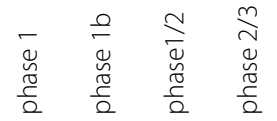
a

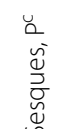

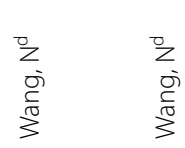

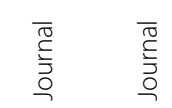

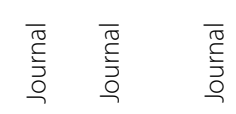

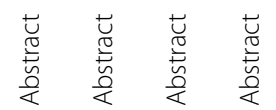

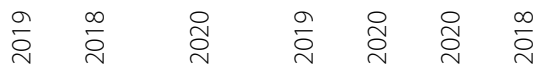

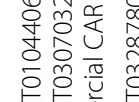

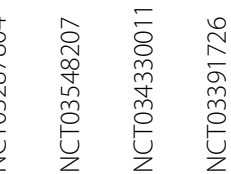

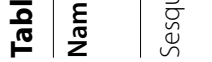

$$
\text { s. }
$$




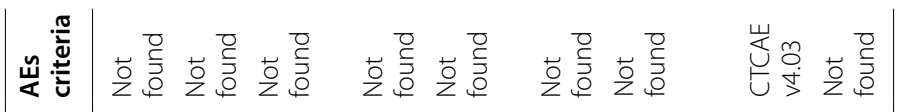

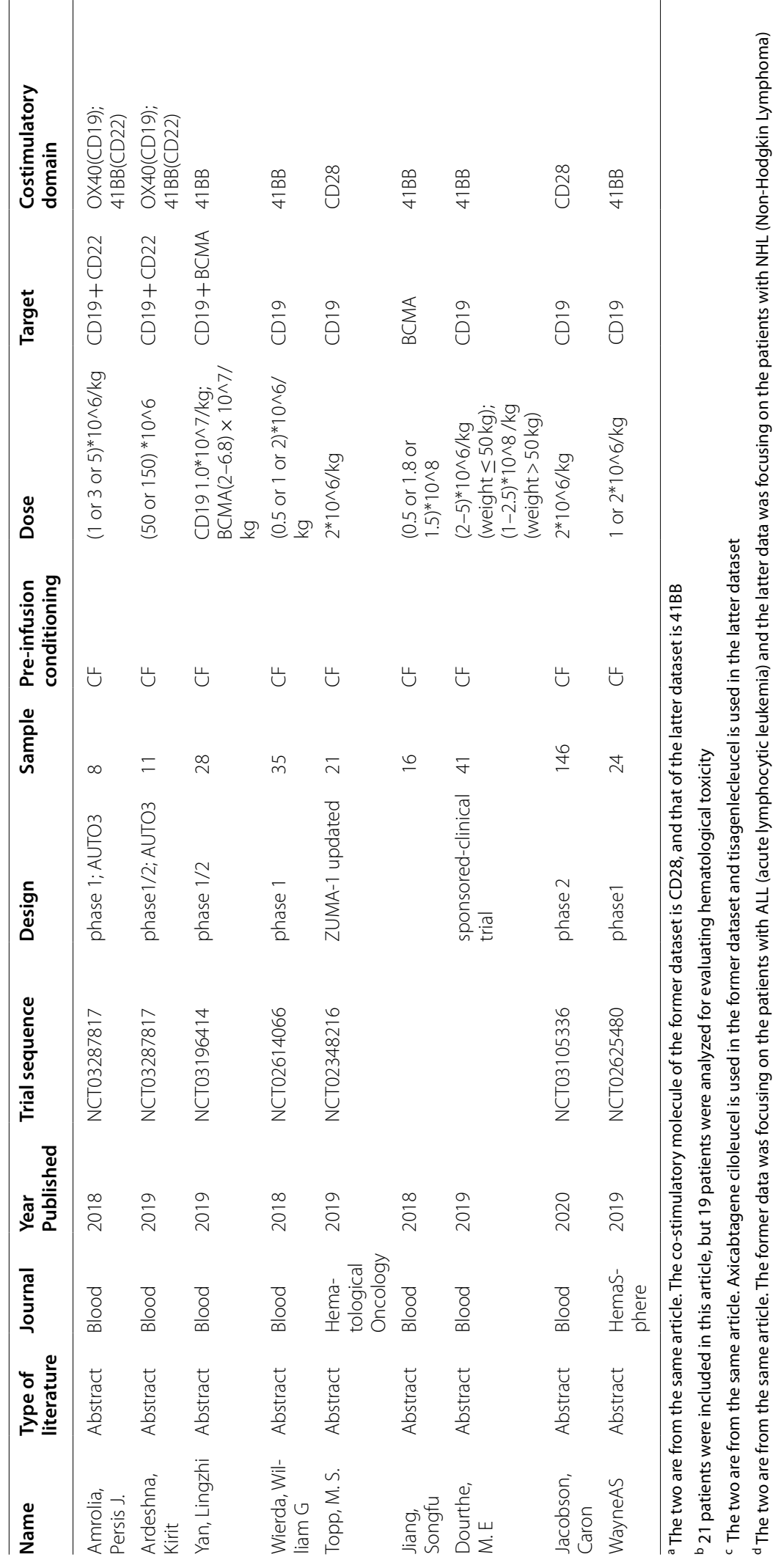


Table 2 Basic characteristics of the included patients

\begin{tabular}{|c|c|c|c|c|c|c|}
\hline Name & Disease & Sample & $\begin{array}{l}\text { Sex } \\
\text { (male\%) }\end{array}$ & $\begin{array}{l}\text { Age } \\
\text { [median(range)] }\end{array}$ & Prior therapy lines & HSCT\% \\
\hline Abramson, J. S & lymphoma & 269 & $65 \%$ & $63(54-70)$ & $\geq 3$ lines: $51 \%$ & $35 \%$ \\
\hline Zhiling Yan & $\mathrm{MM}$ & 21 & $48 \%$ & $58(49.5-61)$ & mean lines: 6 & $14 \%$ \\
\hline Ali, S. A & MM & 12 & & & median lines: 7 & $100 \%$ \\
\hline Cohen, A. D & MM & 25 & $68 \%$ & $58(44-75)$ & median(range) lines: 7(3-13) & $92 \%$ \\
\hline Curran, K. J & ALL & 25 & & $13.5(1-22.5)$ & Not found & $20 \%$ \\
\hline Enblad, Gunilla & lymphoma+ALL & 15 & $47 \%$ & $61(24-71)$ & mean lines: 1.73 & $40 \%$ \\
\hline Fry, T. J & B-ALL & 21 & $62 \%$ & 19(7-30) & Not found & $90 \%$ \\
\hline Gardner, R. A & B-ALL & 43 & $44 \%$ & $12.3(1.3-25.4)$ & Not found & $62 \%$ \\
\hline Geyer, M. B. & $C L L$ & 8 & $100 \%$ & $58(45-70)$ & Not found & \\
\hline Geyer, M. B & $\mathrm{CLL}+\mathrm{NHL}$ & 20 & $70 \%$ & $63(43-75)$ & $\begin{array}{l}\text { median(range) lines: } \\
4(1-11)\end{array}$ & 0 \\
\hline Goto, $\mathrm{H}$ & $\mathrm{DLBCL}$ & 9 & $56 \%$ & $61(32-73)$ & mean lines; 3 & $44.40 \%$ \\
\hline Fried, S. & $\mathrm{ALL}+\mathrm{NHL}$ & 35 & $71 \%$ & $27(3.5-55)$ & Not found & $37 \%$ \\
\hline Lee, D.W & $A L L+D L B C L$ & 19 & $67 \%$ & 1 to 30 & mean lines: 2 & $38 \%$ \\
\hline Locke, F. L & lymphoma & 108 & $68 \%$ & $\begin{array}{l}\text { Phase 1: } \\
59 \text { (IQR34-69);Phase 2: } \\
58 \text { (IQR51-64) }\end{array}$ & median lines: 3 & $23 \%$ \\
\hline Maude, S. L & ALL & 75 & $57 \%$ & $11(3-23)$ & $\begin{array}{l}\text { median(range) lines: } \\
3(1-8)\end{array}$ & $61 \%$ \\
\hline $\mathrm{Xu}, \mathrm{J}$ & MM & 17 & $65 \%$ & $55(40-73)$ & $\begin{array}{l}\text { median(range) lines: } \\
5(3-11)\end{array}$ & $47 \%$ \\
\hline Schuster, S. J & DLBCL & 111 & $65 \%$ & $56(22-76)$ & $\geq 3$ lines: $52 \%$ & $49 \%$ \\
\hline Raje, N & MM & 33 & $64 \%$ & $60(37-75)$ & median(range) lines: 7(3-23) & $97 \%$ \\
\hline Schuster, S. J & $F C L+D L B C L$ & 28 & $64 \%$ & $57.5(25-77)$ & median(range) lines: $4.5(1-10)$ & $39 \%$ \\
\hline Wang, $\mathrm{N}^{\mathrm{a}}$ & ALL & 51 & $63 \%$ & $27(9-62)$ & Not found & $24 \%$ \\
\hline Wang, $N^{a}$ & $\mathrm{NHL}$ & 38 & $58 \%$ & $47(17-71)$ & Not found & $15.80 \%$ \\
\hline Zhao, W. H & MM & 57 & $60 \%$ & $54(27-72)$ & median(range) lines: 3 (1-9) & $18 \%$ \\
\hline Wang, M & MM & 68 & $84 \%$ & $65(38-79)$ & $\begin{array}{l}\geq 3 \text { lines } 81 \% \text {; } \\
\text { median(range) lines: } 3(1-5)\end{array}$ & $43 \%$ \\
\hline Sang, W & DLBCL & 21 & $62 \%$ & $55(23-72)$ & median(range) lines: 3(1-6) & $5 \%$ \\
\hline Wayne AS, & $\mathrm{ALL}$ & 24 & $63 \%$ & 13(3-20) & $\geq 3$ lines: $42 \%$ & $25 \%$ \\
\hline Ghorashian, S & ALL & 14 & $93 \%$ & $9.24(1.35-19.28)$ & median(range) lines: $4(2-7)$ & $71 \%$ \\
\hline Wang, Jia & ALL & 23 & $61 \%$ & $42(10-67)$ & median(range) lines: 2(2-3) & $22 \%$ \\
\hline Bao, F. & $\mathrm{ALL}+\mathrm{NHL}$ & 10 & $40 \%$ & $33.5(25-69)$ & Not found & \\
\hline Hu, Jianda & DLBCL & 8 & & $52(27-70)$ & Not found & \\
\hline Jiang, Songfu & MM & 16 & & $55(39-67)$ & $\begin{array}{l}\text { median(range) lines: } \\
4(2-10)\end{array}$ & $56 \%$ \\
\hline Wierda, William G & ALL & 35 & $51 \%$ & $40(18-69)$ & $\geq 3$ lines: $60 \%$ & \\
\hline Yan, Lingzhi & MM & 28 & $82 \%$ & $57.5(42-69)$ & mean(range) lines: $3(2-8)$ & \\
\hline Amrolia, Persis J. & $\mathrm{ALL}$ & 8 & & $7.5(4-16)$ & Not found & $63 \%$ \\
\hline Ardeshna, Kirit & DLBCL & 11 & & 49 & median lines: 3 & $27 \%$ \\
\hline Strati, Paolo & lymphoma & 31 & $74 \%$ & $52(23-76)$ & $\begin{array}{l}\text { >3lines } 45 \% \text {; } \\
\text { median(range) lines: } 3(1-11)\end{array}$ & $35 \%$ \\
\hline Yan, Zi-Xun & $\mathrm{NHL}$ & 10 & $80 \%$ & $47(32-59)$ & $\geq 3$ lines: $100 \%$ & \\
\hline Ying, Zhitao ${ }^{b}$ & $\mathrm{NHL}$ & 3 & $67 \%$ & $<65$ & mean lines: 9.7 & 0 \\
\hline Ying, Zhitao ${ }^{b}$ & $\mathrm{NHL}$ & 3 & $100 \%$ & $<65$ & mean lines: 8 & 0 \\
\hline Topp, M. S. & lymphoma & 21 & $67 \%$ & $63(36-73)$ & $\geq 2$ lines: $76 \%$ & $10 \%$ \\
\hline$A n, F$ & ALL & 47 & $49 \%$ & $22(3-72)$ & $<10$ lines: $59.6 \%$ & $19.10 \%$ \\
\hline Dourthe, M. E & ALL & 41 & & $18.2(1-29.2)$ & Not found & $63 \%$ \\
\hline Mailankody, S & MM & 51 & & $61(33-77)$ & median(range) lines: 6 (3-18) & \\
\hline Popat, R & MM & 11 & & $61(45-69)$ & median(range) lines: 5(3-6) & $73 \%$ \\
\hline
\end{tabular}


Table 2 (continued)

\begin{tabular}{|c|c|c|c|c|c|c|}
\hline Name & Disease & Sample & $\begin{array}{l}\text { Sex } \\
\text { (male\%) }\end{array}$ & $\begin{array}{l}\text { Age } \\
\text { [median(range)] }\end{array}$ & Prior therapy lines & HSCT\% \\
\hline Ramos, C. A & $\mathrm{HL}$ & 42 & $67 \%$ & $35(17-69)$ & median(range) lines: 7(2-23) & $100 \%$ \\
\hline Sesques, $P^{c}$ & DLBCL & 33 & $72 \%$ & $62(28-75)$ & $\geq 4$ lines: $64 \%$ & $30 \%$ \\
\hline Sesques, $P^{c}$ & DLBCL & 28 & $57 \%$ & $59(27-72)$ & $\geq 4$ lines: $79 \%$ & $29 \%$ \\
\hline Shah, N. N & lymphoma & 22 & $86 \%$ & $57(38-72)$ & Not found & $50 \%$ \\
\hline Tong, C & $\mathrm{NHL}$ & 28 & $39 \%$ & & $\geq 3$ lines: $79 \%$ & \\
\hline Usmani, S. Z & MM & 29 & & & median(range) lines: 5(3-18) & \\
\hline Wang, Y & ALL & 21 & $52 \%$ & $13(3-69)$ & median(range) lines: 4(1-7) & $9.52 \%$ \\
\hline Zhou, X & $\mathrm{NHL}+\mathrm{DLBCL}$ & 21 & $62 \%$ & 31 to 77 & $\geq 4$ lines: $38 \%$ & \\
\hline Ramos, Carlos A & $\mathrm{NHL}$ & 16 & & $67(17-73)$ & Not found & $31 \%$ \\
\hline Zhang, W. Y & $\mathrm{NHL}$ & 11 & & $\geq 18$ & Not found & $9 \%$ \\
\hline Jain, $T$ & $\mathrm{NHL}+\mathrm{ALL}+\mathrm{MM}$ & 83 & $67 \%$ & $58(19-85)$ & Not found & $37 \%$ \\
\hline Jacobson, Caron & iNHL & 146 & $57 \%$ & $61(34-79)$ & median(range) lines: 3(1-10) & \\
\hline
\end{tabular}

a The two are from the same article. The former data was focusing on the patients with ALL (acute lymphocytic leukemia) and the latter data was focusing on the patients with $\mathrm{NHL}$ (Non-Hodgkin Lymphoma)

b The two are from the same article. The co-stimulatory molecule of the former dataset is CD28, and that of the latter dataset is 41BB

c The two are from the same article. Axicabtagene ciloleucel is used in the former dataset and tisagenlecleucel is used in the latter dataset

extracted data. As shown in Tables 5 and 6, the results showed that the hematological toxicity was more frequent in cases where the co-stimulatory molecule was $\mathrm{CD} 28$, and the $\mathrm{Z}$ tests showed that the differences were significant in analyzing thrombocytopenia and any grades anemia. In other words, the co-stimulatory molecule of CD28 has greater tendency to induce hematological toxic effects than that of $41 \mathrm{BB}$. The conclusion is in line with previous studies reporting that 41BB CAR-T cells resulted in less severe AEs [62].

\section{Onset time of hematological toxicity}

In this part, we only conducted analysis qualitatively. The study by Fried S et al. [16] reported that the median time to onset of neutropenia was 3 days (range 0-21) and severe neutropenia occurred within a median of 7 days (range 0-63), and they reported that the median time to onset of thrombocytopenia was 0 days (range 0-38) and that of grade $\geq 3$ was 5.5 days (range $0-28$ ). That is, hematological occurred early in the process of CAR-T therapy. Besides, Wang J et al. [43] reported that grade $\geq 3$ hematological toxicity mostly occurred 5 days after pretreatment. And in general, conditioning chemotherapy was conducted 3-5 days before infusion. It was reported that hematological toxicity after CAR-T was in fact associated with lymphodepleting chemotherapy [25]. However, even though it is pretreatment but not the CAR-T cell itself leading to hematological toxicity in mechanism, since conditioning regimen was an important part of CAR-T therapy procedure, we should conclude that CAR-T therapy was related to the toxicity of blood system. Furthermore, the facts listed above were important reminders for us to note the hematological toxic effects shortly after initiating CAR-T therapy.

\section{Recovery time of hematological toxicity}

We analyzed hematological toxicity on day 28 and on the 3rd month after infusion. However, because of the limitations of the extracted data, we only explored the grade $\geq 3$ cytopenia, neutropenia and thrombocytopenia, and the calculated data is presented in Table 4. On D28 after infusion, the pooled results of grade $\geq 3$ cytopenia, neutropenia and thrombocytopenia were 39\% (95\%CI: 24-55\%), 13\% (95\%CI: 5-25\%) and 25\% (95\%CI: 19-36\%) respectively. On the 3rd month, the grade $\geq 3$ neutropenia was $5 \%$ (95\%CI: $0-16 \%$ ), and grade $\geq 3$ thrombocytopenia was $20 \%$ (95\%CI: $8-35 \%$ ). Both time points of day 28 and the 3rd month witnessed higher thrombocytopenia than neutropenia. And as shown in Table 4, the overall incidences of neutropenia were more frequent than thrombocytopenia. An explanation is that platelets are more difficult to recover than neutrophils, consistent with the conclusion of one study by Jain $\mathrm{T}$ et al. [46]. They demonstrated that hematological count "normalization" (in the normal range for the laboratory) was much easier for neutrophils than hemoglobin and platelets.

\section{Sensitivity analysis and publication bias}

Sensitivity analysis was performed in overall rate of the hematological toxicity. And the results showed that after omitting the studies one by one, the pooled results did not change significantly. In other words, the results of the meta-analysis were stable enough (Fig. 3). Egger test was 
Table 3 Risk of bias

\begin{tabular}{|c|c|c|c|c|c|}
\hline Study & Selection & Ascertainment & Causality & Reporting & Risk of bias \\
\hline Ying et al & & & & $x$ & Low \\
\hline Yan et al & & & & $x$ & Low \\
\hline Sang et al & & & & $x$ & Low \\
\hline Tong et al & & & & $x$ & Low \\
\hline Xu et al & & & & $x$ & Low \\
\hline Zhao et al & & & & $x$ & Low \\
\hline Shah et al & & & & $x$ & Low \\
\hline Wang et al & $x$ & & & $x$ & Moderate \\
\hline Fried et al & & & & $x$ & Low \\
\hline An et al & $x$ & & & $x$ & Moderate \\
\hline Ramos et al & $x$ & & & $x$ & Moderate \\
\hline Raje et al & & & & $x$ & Low \\
\hline Abramson et al & $x$ & & & $x$ & Moderate \\
\hline Wang et al & $x$ & & & $x$ & Moderate \\
\hline Cohen et al & $x$ & & & $x$ & Moderate \\
\hline Goto et al & $x$ & & & & Low \\
\hline Schuster et al & $x$ & & & $x$ & Moderate \\
\hline Ghorashian et al & $x$ & & & $x$ & Moderate \\
\hline Maude et al & & & & $x$ & Low \\
\hline Strati et al & & & & & Low \\
\hline Locke et al & & & & $x$ & Low \\
\hline Fry et al & & & & & Low \\
\hline Ali et al & & & & $x$ & Low \\
\hline Enblad et al & & & & & Low \\
\hline Schuster et al & $x$ & & & $x$ & Moderate \\
\hline Gardner et al & & & & $x$ & Low \\
\hline Curran et al & $x$ & & & & Low \\
\hline Ramos et al & & & & & Low \\
\hline Zhang et al & & & & & Low \\
\hline Lee et al & & & $x$ & $x$ & Moderate \\
\hline Geyer et al & & & & & Low \\
\hline Geyer et al & & & & & Low \\
\hline Sesques et al & $x$ & & & & Low \\
\hline Wang et al & & & & $x$ & Low \\
\hline Zhou et al & & & & $x$ & Low \\
\hline Wang et al & $x$ & & & $x$ & Moderate \\
\hline Yan et al & $x$ & & & $x$ & Moderate \\
\hline Bao et al & & $x$ & & $x$ & Moderate \\
\hline Jain et al & & & $x$ & & Low \\
\hline
\end{tabular}

Evaluation of methodological quality. Negative points are denoted with " $\mathrm{X}$ ". Score of 0-1 suggests low risk of bias, 2-3 moderate, and 4 high

conducted for analyzing publication bias in evaluating overall incidences of neutropenia, thrombocytopenia and anemia. If $P$ value $>0.05$ was met in analyzing, it was considered as having no publication bias (data not shown). The funnel plots of Egger tests are shown in Fig. 4. Publication bias did not occur in all six groups.

\section{Coagulation toxicity}

Pooling data of the data indicated that the incidences of any grades APTT prolongation and fibrinogenopenia were 56\% (95\%CI: $31-79 \%$ ) and 13\% (95\%CI: 6-22\%) respectively, and that proportion of $\geq 3$ grade APTT prolongation and fibrinogenopenia were $4 \%$ (95\%CI: 2-79\%) and 5\% (95\%CI: 2-9\%) (Table 4). Furthermore, we performed the subgroup analysis of any grades APTT 


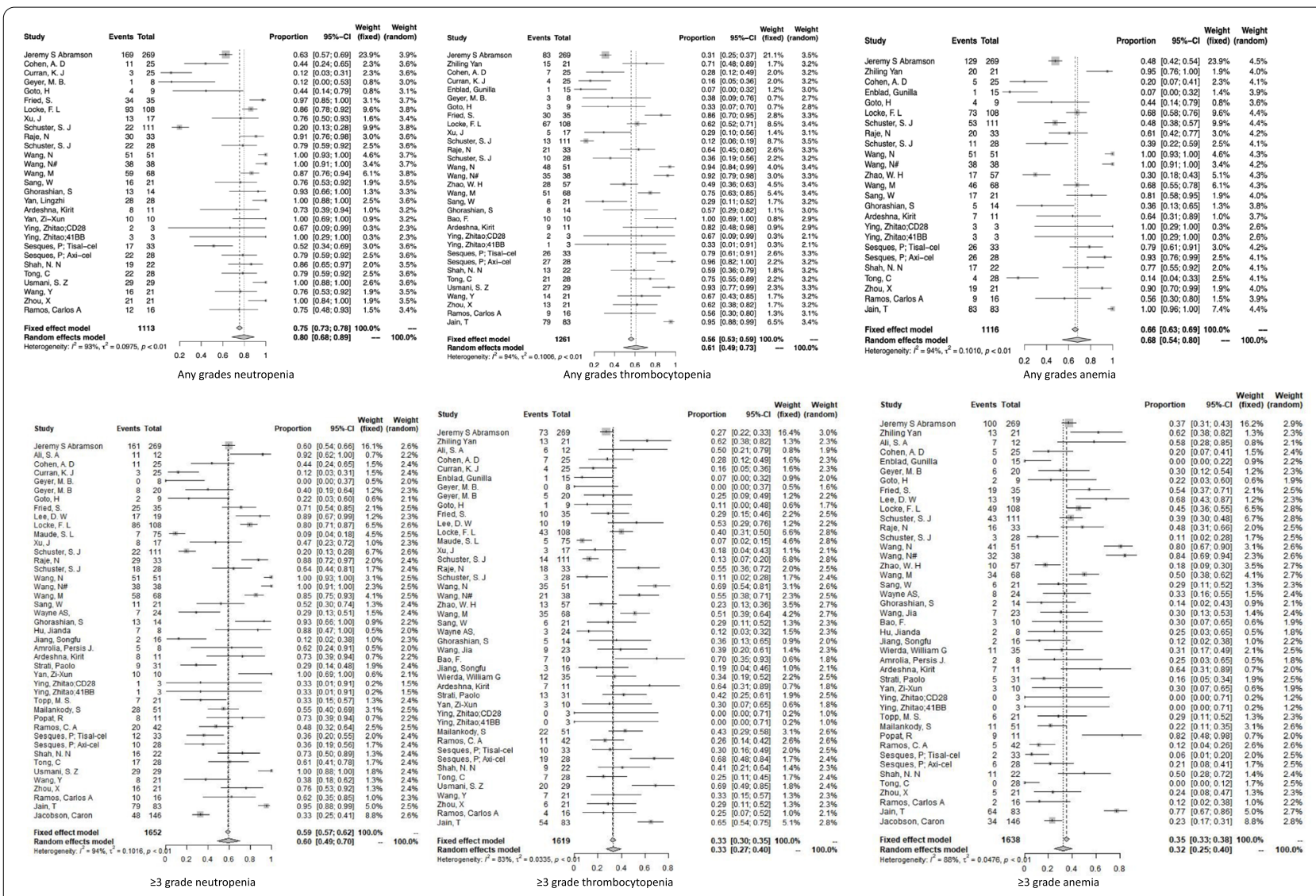

Fig. 2 Forest plots of hematological toxicity

Table 4 overall incidence rate of adverse effects

\begin{tabular}{llll}
\hline & Pooled results & $\mathbf{9 5 \%} \mathbf{C l}$ & $\mathbf{I}^{\mathbf{2}}$ \\
\hline Any grades AEs & & & \\
Neutropenia & $80 \%$ & $68-89 \%$ & $93 \%$ \\
Thrombocytopenia & $61 \%$ & $49-73 \%$ & $94 \%$ \\
Anemia & $68 \%$ & $54-80 \%$ & $94 \%$ \\
AST increased & $28 \%$ & $18-43 \%$ & $92 \%$ \\
ALT increased & $30 \%$ & $26-34 \%$ & $39 \%$ \\
Serum creatine increased & $14 \%$ & $8-24 \%$ & $82 \%$ \\
APTT prolonged & $56 \%$ & $31-79 \%$ & $94 \%$ \\
Fibrinogen decreased & $13 \%$ & $6-22 \%$ & $72 \%$ \\
Serum creatine increased & $14 \%$ & $8-24 \%$ & $82 \%$ \\
$\geq 3$ grade AEs & & & \\
Neutropenia & $60 \%$ & $49-70 \%$ & $94 \%$ \\
Thrombocytopenia & $33 \%$ & $27-40 \%$ & $83 \%$ \\
Anemia & $32 \%$ & $25-40 \%$ & $88 \%$ \\
AST increased & $6 \%$ & $3-10 \%$ & $51 \%$ \\
ALT increased & $2 \%$ & $1-3 \%$ & $0 \%$ \\
Serum creatine increased & $1 \%$ & $0-2 \%$ & $0 \%$ \\
APTT prolonged & $4 \%$ & $1-8 \%$ & $0 \%$ \\
\hline
\end{tabular}

prolongation and fibrinogenopenia by pathological type (just in cases of "leukemia" and "MM"). As shown in Tables 5 and 6, the difference between the two subgroups was not statistically significant. The incidences of APTT prolongation were 50\% (95\% CI: $3-97 \%)$ and 39\% (95\% CI: $10-73 \%)$ in leukemia cases and MM cases respectively. And the pooled results showed that the rates of any grades fibrinogenopenia were comparable in the two subgroups of leukemia (12\%) and MM (16\%).

\section{Hepatotoxicity}

Meta-analysis showed that rates of any grades AST and ALT increasement were 28\% (95\%CI: 18-43\%) and $29 \%$ (95\% CI: $24-35 \%)$ respectively, and that incidences of grade $\geq 3$ AST and ALT increasement were 6\% (95\%CI: $3-10 \%)$ and $2 \%$ (95\%CI: $1-3 \%$ ) (Table 4 ). We also performed subgroup analysis by pathological type in this part and the additional data is presented in Tables 5 and 6 in detail.

\section{Nephrotoxicity}

To explore the effect of CAR-T cell therapy on renal function, we conducted an analysis on data about 
Table 5 Subgroup analysis of hematological toxicity

\begin{tabular}{|c|c|c|c|c|c|c|c|c|}
\hline \multicolumn{9}{|c|}{ Any grades of hematological toxicity } \\
\hline & & & Neutropenia & & Thrombocytopenia & & Anemia & \\
\hline \multirow[t]{6}{*}{ Median age (years) } & $<45$ & rate $^{\mathrm{a}}$ & $82 \%(42-100 \%)$ & $P>0.05$ & $74 \%(44-95 \%)$ & $P>0.05$ & $79 \%(4-100 \%)$ & $P>0.05$ \\
\hline & & $N^{b}$ & 146 & & 156 & & 65 & \\
\hline & $\geq 45$ and $<60$ & rate & $82 \%(64-96 \%)$ & & $57 \%(39-75 \%)$ & & $77 \%(59-92 \%)$ & \\
\hline & & N & 565 & & 605 & & 580 & \\
\hline & $>60$ & rate & $72 \%(56-85 \%)$ & & $50 \%(28-71 \%)$ & & $53 \%(39-68 \%)$ & \\
\hline & & N & 428 & & 443 & & 443 & \\
\hline \multirow[t]{6}{*}{ Pathological type } & leukemia & rate & $62 \%(17-98 \%)$ & $P>0.05$ & $60 \%(22-93 \%)$ & $P>0.05$ & $69 \%(17-100 \%)$ & $P>0.05$ \\
\hline & & N & 244 & & 254 & & 176 & \\
\hline & lymphoma & rate & $83 \%(73-90 \%)$ & & $60 \%(46-73 \%)$ & & $68 \%(54-80 \%)$ & \\
\hline & & N & 737 & & 742 & & 721 & \\
\hline & MM & rate & $88 \%(64-100 \%)$ & & $57 \%(36-77 \%)$ & & $53 \%(21-84 \%)$ & \\
\hline & & N & 132 & & 182 & & 136 & \\
\hline \multirow[t]{4}{*}{ Targeting antigen } & CD19 & rate & $73 \%(58-86 \%)$ & $P=0.0001$ & $56 \%(40-71 \%)$ & $P>0.05$ & $64 \%(48-79 \%)$ & $P>0.05$ \\
\hline & & N & 918 & & 933 & & 834 & \\
\hline & non-CD19 & rate & 93\% (84-99\%) & & $70 \%(54-83 \%)$ & & $74 \%(46-95 \%)$ & \\
\hline & & N & 278 & & 328 & & 282 & \\
\hline \multirow[t]{4}{*}{ Proportion of previous HSCT } & $<50 \%$ & rate & $80 \%(56-97 \%)$ & $P>0.05$ & $74 \%$ (58-87\%) & $P>0.05$ & $74 \%(58-87 \%)$ & $P>0.05$ \\
\hline & & N & 978 & & 1071 & & 973 & \\
\hline & $\geq 50 \%$ & rate & $77 \%$ (62-89\%) & & $52 \%(34-69 \%)$ & & $49 \%(23-74 \%)$ & \\
\hline & & N & 94 & & 94 & & 94 & \\
\hline \multirow[t]{4}{*}{ Median lines of prior therapy } & $<4$ & rate & $79 \%(61-93 \%)$ & $P>0.05$ & $42 \%(27-58 \%)$ & $P=0.0252$ & $55 \%(43-67 \%)$ & $P>0.05$ \\
\hline & & N & 673 & & 707 & & 690 & \\
\hline & $\geq 4$ & rate & $81 \%(69-92 \%)$ & & $67 \%(53-80 \%)$ & & $65 \%(43-84 \%)$ & \\
\hline & & N & 267 & & 288 & & 238 & \\
\hline \multirow[t]{4}{*}{ Co-stimulatory molecule } & CD28 & rate & $88 \%(82-93 \%)$ & $P>0.05$ & 79\% (59-94\%) & $P=0.0054$ & $79 \%(64-92 \%)$ & $P=0.0274$ \\
\hline & & N & 207 & & 207 & & 207 & \\
\hline & $41 \mathrm{BB}$ & rate & $65 \%(41-86 \%)$ & & $36 \%(17-57 \%)$ & & $55 \%(42-67 \%)$ & \\
\hline & & N & 463 & & 453 & & 453 & \\
\hline \multirow[t]{4}{*}{ Median age in leukemia cases } & $<20$ & rate & $61 \%(10-100 \%)$ & $P>0.05$ & $45 \%(14-79 \%)$ & $P=0.032$ & No analysis & \\
\hline & & N & 60 & & 60 & & & \\
\hline & $\geq 20$ & rate & $83 \%(38-100 \%)$ & & $87 \%$ (66-99\%) & & & \\
\hline & & N & 94 & & 104 & & & \\
\hline \multirow[t]{4}{*}{ Median age in lymphoma cases } & $<60$ & rate & 85\% (63-99\%) & $P>0.05$ & $59 \%(35-81 \%)$ & $P>0.05$ & $80 \%(64-93 \%)$ & $P=0.0424$ \\
\hline & & N & 404 & & 394 & & 394 & \\
\hline & $\geq 60$ & rate & $67 \%(51-81 \%)$ & & $47 \%(23-72 \%)$ & & $52 \%(34-69 \%)$ & \\
\hline & & $\mathrm{N}$ & 395 & & 410 & & 410 & \\
\hline \multicolumn{9}{|c|}{$\geq 3$ grade of hematological toxicity } \\
\hline & & & Neutropenia & & Thrombocytopenia & & Anemia & \\
\hline \multirow[t]{6}{*}{ Median age (years) } & $<45$ & rate & $57 \%(28-84 \%)$ & $P>0.05$ & $33 \%(20-47 \%)$ & $P>0.05$ & $38 \%(22-56 \%)$ & $P>0.05$ \\
\hline & & $\mathrm{N}$ & 314 & & 374 & & 261 & \\
\hline & $\geq 45$ and $<60$ & rate & $59 \%(40-76 \%)$ & & $32 \%(22-43 \%)$ & & $34 \%(22-46 \%)$ & \\
\hline & & N & 592 & & 662 & & 645 & \\
\hline & $>60$ & rate & $59 \%(45-71 \%)$ & & $32 \%(23-43 \%)$ & & $28 \%(18-40 \%)$ & \\
\hline & & N & 531 & & 514 & & 546 & \\
\hline
\end{tabular}


Table 5 (continued)

\begin{tabular}{|c|c|c|c|c|c|c|c|c|}
\hline \multirow[t]{6}{*}{ Pathological type } & leukemia & rate & $48 \%(22-76 \%)$ & $P>0.05$ & $28 \%(16-42 \%)$ & $P>0.05$ & $41 \%(28-54 \%)$ & $P>0.05$ \\
\hline & & N & 390 & & 450 & & 350 & \\
\hline & lymphoma & rate & $60 \%(49-71 \%)$ & & $32 \%(25-40 \%)$ & & $24 \%(16-34 \%)$ & \\
\hline & & N & 985 & & 825 & & 979 & \\
\hline & MM & rate & $58 \%(29-84 \%)$ & & $40 \%(28-53 \%)$ & & $31 \%(15-50 \%)$ & \\
\hline & & N & 215 & & 261 & & 350 & \\
\hline \multirow[t]{4}{*}{ Targeting antigen } & CD19 & rate & $52 \%(40-64 \%)$ & $P=0.0088$ & $29 \%(22-36 \%)$ & $P>0.05$ & $28 \%(21-35 \%)$ & $P>0.05$ \\
\hline & & N & 1313 & & 1221 & & 1267 & \\
\hline & non-CD19 & rate & $75 \%(57-90 \%)$ & & $43 \%(32-54 \%)$ & & $42 \%(24-62 \%)$ & \\
\hline & & N & 339 & & 398 & & 371 & \\
\hline \multirow[t]{4}{*}{ Proportion of previous HSCT } & $<50 \%$ & rate & $58 \%(44-71 \%)$ & $P>0.05$ & $33 \%(26-41 \%)$ & $P>0.05$ & $36 \%(26-45 \%)$ & $P>0.05$ \\
\hline & & N & 1093 & & 1180 & & 1146 & \\
\hline & $\geq 50 \%$ & rate & $59 \%(34-82 \%)$ & & $30 \%(16-46 \%)$ & & $34 \%(19-50 \%)$ & \\
\hline & & N & 258 & & 239 & & 183 & \\
\hline \multirow[t]{4}{*}{ Median lines of prior therapy } & $<4$ & rate & $53 \%(38-68 \%)$ & $P>0.05$ & $28 \%(20-36 \%)$ & $P>0.05$ & $32 \%(25-39 \%)$ & $P>0.05$ \\
\hline & & N & 961 & & 924 & & 999 & \\
\hline & $\geq 4$ & rate & $60 \%(46-73 \%)$ & & $34 \%(24-43 \%)$ & & $24 \%(13-36 \%)$ & \\
\hline & & N & 419 & & 440 & & 390 & \\
\hline \multirow[t]{4}{*}{ Co-stimulatory molecule } & CD28 & rate & $47 \%(34-66 \%)$ & $P>0.05$ & $47 \%(34-60 \%)$ & $P=0.0004$ & $29 \%(18-41 \%)$ & $P>0.05$ \\
\hline & & N & 405 & & 238 & & 405 & \\
\hline & $41 \mathrm{BB}$ & rate & $53 \%(38-74 \%)$ & & $18 \%(10-27 \%)$ & & $22 \%(11-34 \%)$ & \\
\hline & & N & 471 & & 463 & & 471 & \\
\hline \multirow[t]{4}{*}{ Median age in leukemia cases } & $<20$ & rate & $46 \%(18-75 \%)$ & $P>0.05$ & $23 \%(10-40 \%)$ & $P>0.05$ & $36 \%(18-70 \%)$ & $P>0.05$ \\
\hline & & N & 186 & & 178 & & 65 & \\
\hline & $\geq 20$ & rate & $58 \%(11-97 \%)$ & & $37 \%(20-56 \%)$ & & $42 \%(28-65 \%)$ & \\
\hline & & N & 114 & & 182 & & 174 & \\
\hline \multirow[t]{4}{*}{ Median age in lymphoma cases } & $<60$ & rate & $64 \%(45-82 \%)$ & $P>0.05$ & $32 \%(22-44 \%)$ & $P>0.05$ & $31 \%(19-43 \%)$ & $P>0.05$ \\
\hline & & N & 485 & & 477 & & 485 & \\
\hline & $\geq 60$ & rate & $49 \%(32-67 \%)$ & & $27 \%(16-40 \%)$ & & $22 \%(12-34 \%)$ & \\
\hline & & N & 562 & & 410 & & 577 & \\
\hline \multirow[t]{4}{*}{ Median age in MM cases } & $<60$ & rate & $34 \%(14-57 \%)$ & $P=0.0227$ & $29 \%(16-44 \%)$ & $P=0.0356$ & $26 \%(9-48 \%)$ & $P>0.05$ \\
\hline & & N & 58 & & 136 & & 119 & \\
\hline & $\geq 60$ & rate & $73 \%(47-93 \%)$ & & $48 \%(37-58 \%)$ & & $48 \%(18-79 \%)$ & \\
\hline & & N & 95 & & 84 & & 95 & \\
\hline
\end{tabular}

a Rate means the pooled results and $95 \% \mathrm{Cl}$ of incidence

${ }^{\mathrm{b}} \mathrm{N}$ means the number of pooled patients in the dataset

serum creatine elevated (SCE). As shown in Table 4, the proportion of any grades SCE was 14\% (95\%CI: 8-24\%), and the incidences of grade $\geq 3$ SCE were quite low. Given that the extracted data of nephrotoxicity was not rich, we did not perform subgroup analysis in this section.

\section{Discussion}

CAR-T cell therapy has dramatical efficacy in hematological malignancies and is developing continuously. There are many articles exploring the pooled complete remission, and the incidence of CRS, as the characteristic adverse effect of CAR-T therapy. However, no study specifically reported the relevant hematological toxicity, coagulation toxicity, hepatotoxicity and nephrotoxicity. The purpose of our meta-analysis was to fill this gap and the main aim was evaluating hematological toxicity after CAR-T infusion.

This meta-analysis showed that the incidence rate of grade $3 / 4$ neutropenia, thrombocytopenia and anemia were 60,33 and $32 \%$, respectively during CAR-T treatment. For lymphoma, these incidences were 60,32 and $24 \%$ correspondingly. For leukemia, they were 48,28 and $41 \%$ correspondingly. For MM, they were 58,40 and $31 \%$ 
Table 6 Subgroup analysis of non-hematological toxicity

\begin{tabular}{|c|c|c|c|c|c|c|}
\hline \multicolumn{7}{|c|}{ Any grades of Coagulation toxicity } \\
\hline & & & APTT prolonged & & Fibrinogen decreased & \\
\hline \multirow[t]{4}{*}{ Pathological type } & leukemia & rate & $50 \%(3-97 \%)$ & $P>0.05$ & $12 \%(7-41 \%)$ & $P>0.05$ \\
\hline & & N & 98 & & 118 & \\
\hline & MM & rate & $59 \%(19-94 \%)$ & & $16 \%(1-41 \%)$ & \\
\hline & & N & 123 & & 103 & \\
\hline \multicolumn{7}{|c|}{ Any grades of Hepatic toxicity } \\
\hline & & & AST increased & & ALT increased & \\
\hline \multirow[t]{6}{*}{ Pathological type } & leukemia & rate & $25 \%(18-32 \%)$ & $P>0.05$ & $34 \%(24-44 \%)$ & $P>0.05$ \\
\hline & & N & 154 & & 93 & \\
\hline & lymphoma & rate & $24 \%(16-34 \%)$ & & $21 \%(15-27 \%)$ & \\
\hline & & N & 249 & & 249 & \\
\hline & MM & rate & $44 \%(14-77 \%)$ & & $25 \%(19-32 \%)$ & \\
\hline & & $\mathrm{N}$ & 120 & & 188 & \\
\hline \multicolumn{7}{|c|}{$\geq 3$ grade of Hepatic toxicity } \\
\hline & & & AST increased & & ALT increased & \\
\hline \multirow[t]{6}{*}{ Pathological type } & leukemia & rate & $7 \%(3-12 \%)$ & $P=0.0016$ & $4 \%(1-7 \%)$ & $P>0.05$ \\
\hline & & N & 236 & & 250 & \\
\hline & lymphoma & rate & $1 \%(0-4 \%)$ & & $1 \%(0-3 \%)$ & \\
\hline & & N & 249 & & 249 & \\
\hline & MM & rate & $16 \%(9-25 \%)$ & & $1 \%(0-4 \%)$ & \\
\hline & & $\mathrm{N}$ & 132 & & 200 & \\
\hline
\end{tabular}

correspondingly. Compared with grade 3/4 CRS from previous reviews [63-65], our pooled results indicated that the most common grade $\geq 3$ AEs were hematological toxic effects. Based on $\mathrm{I}^{2}$ statistic, the results from random-effect model were used to represent overall hematological toxicity. At the same time, subgroup analysis did not reduce heterogeneity. According to subgroup analysis and the corresponding $\mathrm{Z}$ test, hematological toxicity is more frequent in younger patients, in patients with $\geq 4$ median lines of prior therapy and in cases targeting CD19. With specific regards to anti-CD19 CAR-T cell constructs, we focused on lymphoma to explore the difference of hematological toxicity between CD28 and $41 \mathrm{BB}$, as two main co-stimulatory molecules in CAR-T therapy. Consistent with our expectations and similar with other AEs, hematological toxicity was more likely to occur in CD28 cases [62]. Some studies reported that patients with severe neutropenia died from severe infections, and some patients with severe thrombocytopenia died because of intracranial hemorrhage or other lifethreatening bleeding events [11, 21, 28, 43, 44, 66]. In long-term follow-up after CAR-T therapy, most delayed hematological toxicities were not life-threatening and would ameliorate 3 months after treatment $[28,46]$. This reminds us of paying attention to hematological toxicities in the early process of CAR-T therapy. Hepatotoxicity, nephrotoxicity and coagulation disorder are less frequent, compared with hematological toxicity, CRS and ICANS. All of these AEs can reflect the levels of inflammation in patients treated with CAR-T cell, and this meta-analysis provided the pooled results to clinicians for reference.

Cytopenia was common after CAR-T cell infusion. Meanwhile, some studies reported that myelodysplastic syndrome (MDS), characterized as cytopenia, occurred 4-39 months after infusion [27, 28, 46, 67-69]. The mechanism of cytopenia is unclear currently, and it was important to rule out the process of CAR-T therapy or MDS as the cause of cytopenia [68]. However, Strati $\mathrm{P}$ et al. reported that cytopenia at day 30 after infusion was not associated with the later diagnosed MDS statistically [27]. The conclusion denied the association between cytopenia and MDS to some extent. Meanwhile, Jain T et al. deemed that inflammation factors remained significantly associated with hematopoietic recovery at 1 month [46]. In other words, the viewpoints about cytopenia were not consistent. Besides, whether MDS is secondary to CAR-T therapy also remains unclear, although some researchers held the standpoints that MDS were attributed to previous chemotherapies [27, 28]. To figure out the potential mechanism of cytopenia or MDS, more work exploring its etiology is needed.

Cytokine release is a double-edged sword as high cytokine levels can result in severe AEs [70]. CRS, the 


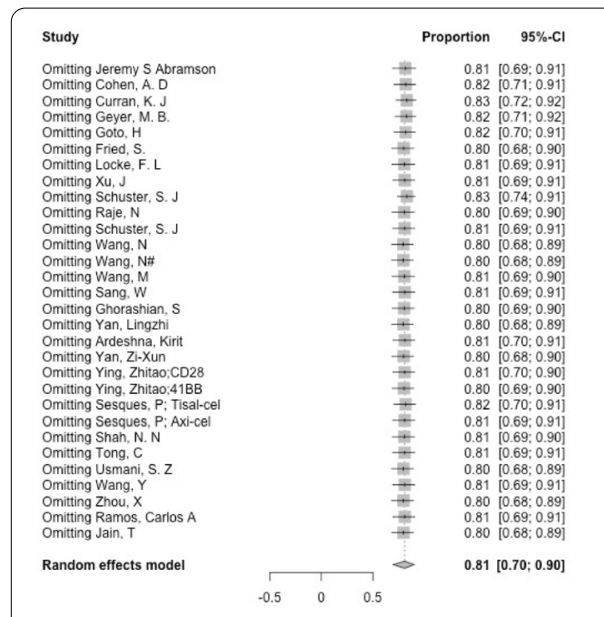

Any grades neutropenia

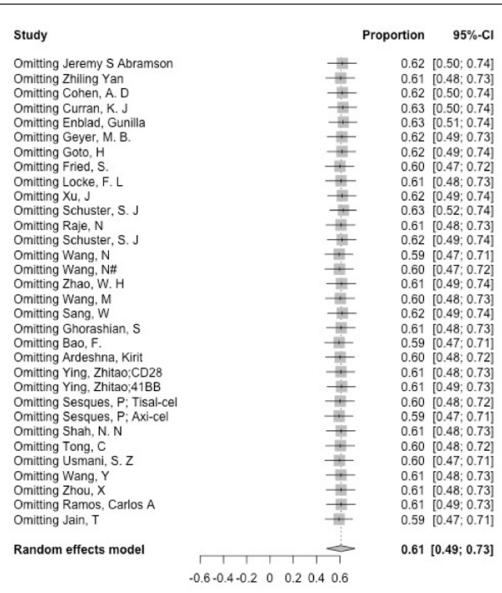

Any grades thrombocytopenia

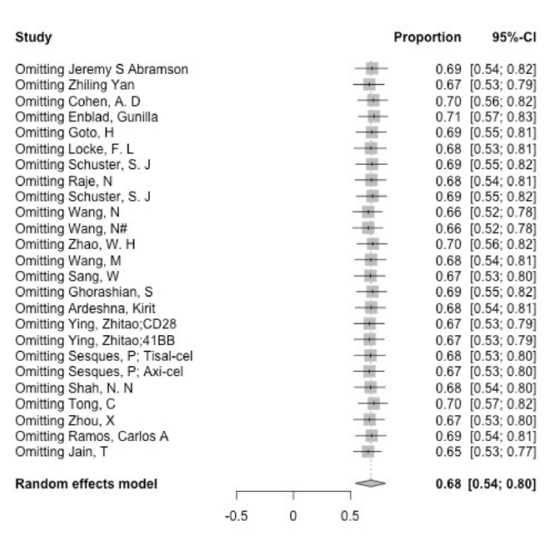

Any grades anemia

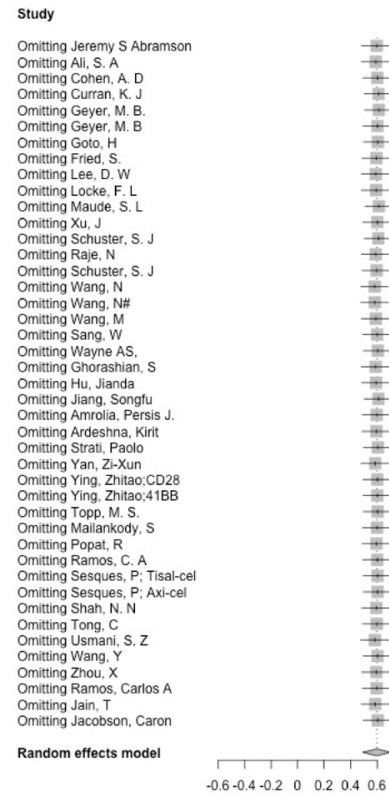

$\geq 3$ grade neutropenia

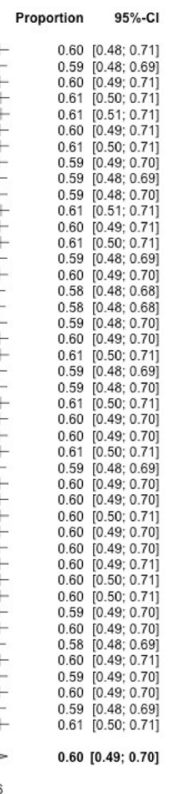

Study

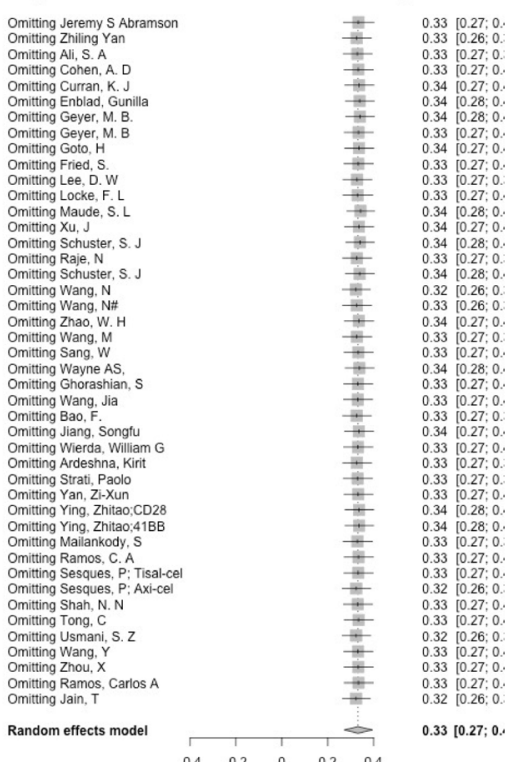

$\geq 3$ grade thrombocytopenia

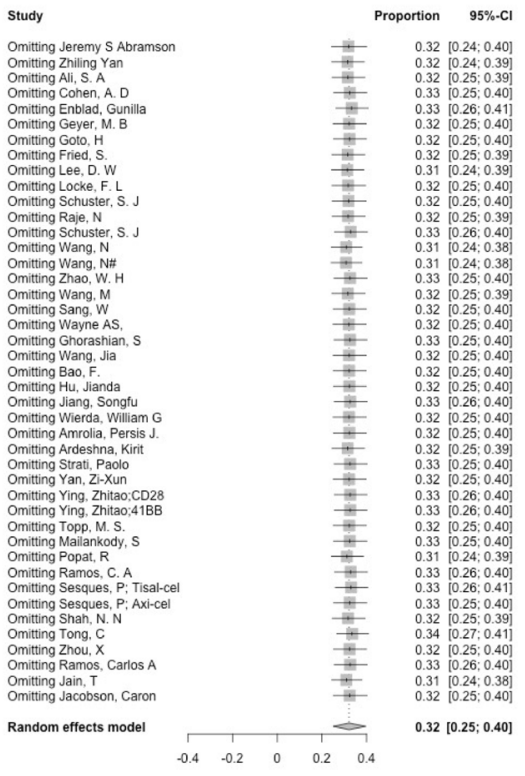

$\geq 3$ grade anemia

Fig. 3 Sensitivity analysis of hematological toxicity

most common toxicity of CAR-T cell therapy, is triggered by engagement of their CARs with the antigen expressed on tumor cells [3]. Hematological toxicities potentially leading to additional complications such as infection or hemorrhage are also associated with cytokine release after CAR-T cell infusion. The study published recently proposed that improved CRS management may improve hematopoietic recovery following CD19 CAR T-cell therapy [4]. Management for CRS and ICANS has been specialized and the related guideline is being constantly being optimized. As hematological toxicities often occur after lymphodepleting chemotherapy, antiviral prophylaxis, i.e. acyclovir, should be started with pretreatment. Antimicrobial and antifungal prophylaxis may be considered when severe or persistent neutropenia happened [71]. Additionally, extended growth factors and transfusional support are needed for hematopoietic recovery [4, 72]. Meanwhile, symptomatic treatment, such as antibiotics and rehydration therapy, and professional nursing are important as well. 


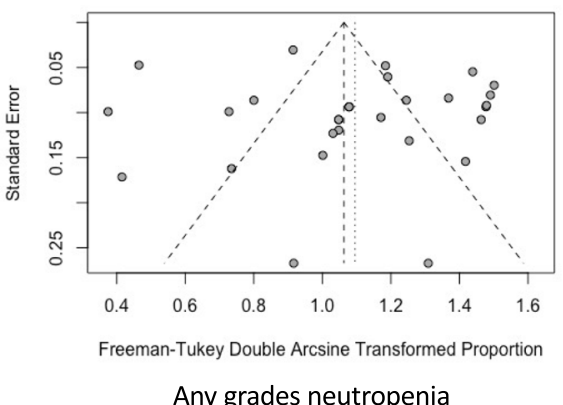

Any grades neutropenia

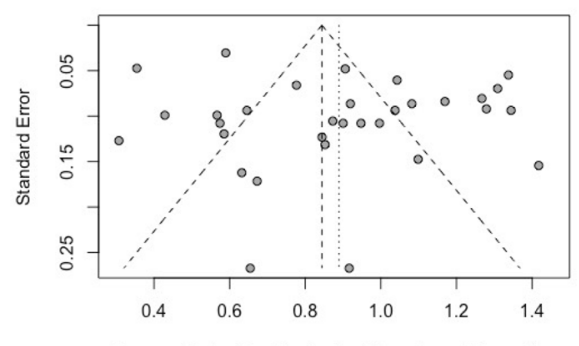

Any grades thrombocytopenia

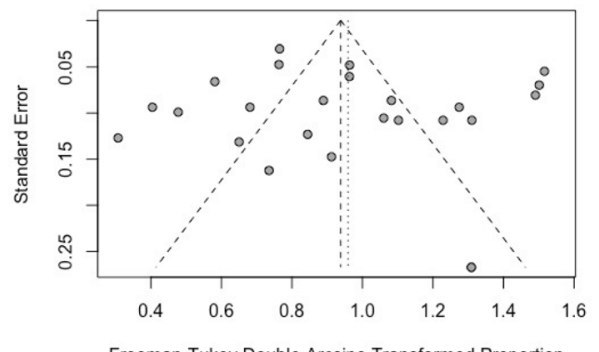

Any grades anemia

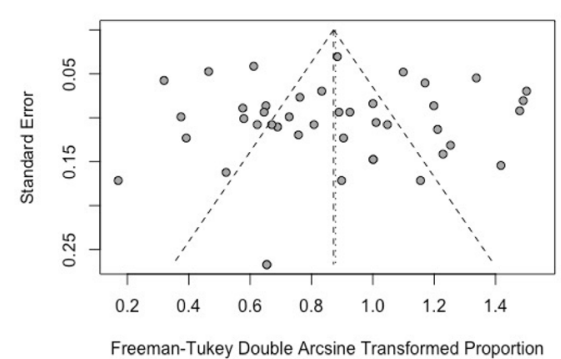

$\geq 3$ grade neutropenia

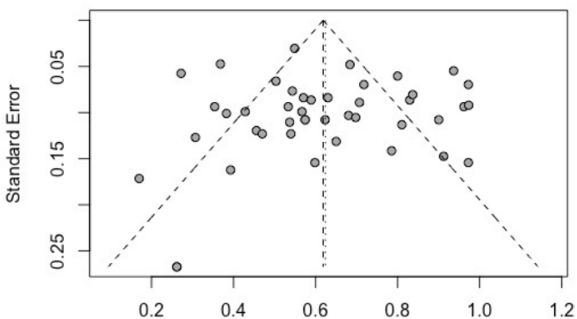

Freeman-Tukey Double Arcsine Transformed Proportion

$\geq 3$ grade thrombocytopenia

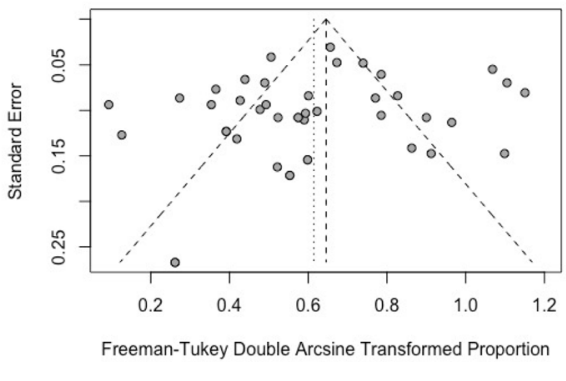

$\geq 3$ grade anemia

Fig. 4 Funnel plots of Egger tests for hematological toxicity

CAR-T cell therapy has achieved dramatical efficacy in ALL, B cell lymphoma and MM, but not in acute myeloid leukemia (AML). What limited the use of CAR-T cell in AML is the absence of specific antigen, as many myeloid antigens also expressed on hematopoietic stem cells which would lead to myelosuppression [3, 73]. Therapeutic approach still needs to be optimize to improve the efficacy and safety of CAR-T cell therapy, such as questing more specific antigens, improving CAR structure, professional management during the CAR-T therapy and application of combination of CAR-T cell and other therapies [71, 72, 74]. Recently, the clinical study showed that CD19-directed CAR-T cell with concurrent ibrutinib for relapsed/refractory $(R / R)$ chronic lymphocytic leukemia
(CLL) led to high rates of MRD-negative with low CRS severity [75].

Compared with previous meta-analysis about CAR-T treatment, the study holds some advantages. We included more studies and targeted not only a single pathological type. Besides, we aimed to analyze hematological toxicity during CAR-T therapy, which was not reported by other systematical reviews. Thirdly, we performed subgroup analysis by age, pathological type, targeting antigen, costimulatory molecule, proportion of HSCT and median lines of prior lines. In addition, we also analyzed hepatotoxicity, nephrotoxicity and coagulation disorder, all of which should be paid attention to but have not been explored previously. 
This meta-analysis has some limitations as well. Firstly, we defined all kinds of lymphoma (DLBCL, MCL, HL, etc.) as "lymphoma", and we set all kinds of leukemia into the "leukemia" subgroup. Some studies pooled all patients with different pathological types together and analyzed the efficacy and safety of CAR-T therapy. When extracting the data in this situation, we deemed the subgroup as the pathological type in majority of the patients included in the study. For example, the study by Shah N. N. et al. [14] included 11 DLBCL patients, $7 \mathrm{MCL}$ patients, 1 FCL patient and 3 CLL patients, so we categorized them as "lymphoma". This method of classification biased the pooled results. Secondly, some articles provided mean lines but not median lines of prior therapy. According to the statistics principle that both mean and median stand for the central tendency of the relevant data, we deemed the mean lines as the corresponding median lines roughly. Additionally, we included some conference proceedings to extract data for analyzing. The data was not detailed as those published in journals, and it might bring bias.

\section{Conclusions}

In conclusion, the CAR-T therapy is associated with hematological toxic effects. And some cases died from infections or severe hemorrhage in early period. In longterm follow-up, the majority of hematological toxicity is less life-threatening and most patients will ameliorate after 3 months. However, more work is needed to explore its mechanism. The significance of this study is to provide the pooled results to clinicians for reference, and to remind them of paying attention to prevention and intervention for hematological toxicity in the early process of CAR-T therapy.

\begin{abstract}
Abbreviations
CAR: Chimeric antigen receptor-modified; HSCT: Hematopoietic stem cell transplantation; AST: Aspartate transferase; ALT: Alanine transaminase; APTT: Activated partial thromboplastin time; Cl: Confidence interval; MM: Multiple myeloma; scFv: Single-chain variable fragment; ICANS: Immune effector cellassociated neurotoxicity syndrome AE: adverse effect; CRS: Cytokine release syndrome; SCE: Serum creatine elevated; MDS: Myelodysplastic syndrome; DLBCL: Diffuse large B cell lymphoma; MCL: Mantle cell lymphoma; HL: Hodgkin lymphoma; FCL: Follicular cell lymphoma; CLL: Chronic lymphocytic leukemia; R/R: Relapsed/refractory.
\end{abstract}

\section{Supplementary Information}

The online version contains supplementary material available at https://doi. org/10.1186/s12885-021-09102-x.

Additional file 1. PRISMA Checklist.

Acknowledgements

Not applicable.

\section{Authors' contributions}

Conception and design of study: HY, MH, LWJ. Acquisition of data: LWJ, LCG, KHM. Analysis and/or interpretation of data: LWJ, ZYQ, DMY. Drafting and revision of manuscript: LWJ, LC. All authors have read and approved the manuscript.

\section{Funding}

This work was supported by grants from the Key Special Project of "Research on Prevention and Control of Major Chronic Non-infectious Diseases" (No. 2019YFC1316203), the National Natural Science Foundation of China (No. 81873434) and Natural Science Foundation of Hubei Province (No. 2020CFA065).

\section{Availability of data and materials}

All data generated or analyzed during this study are included in this published article.

\section{Declarations}

Ethics approval and consent to participate

Not applicable.

\section{Consent for publication}

Not applicable.

\section{Competing interests}

The authors declare that they have no competing interests.

\section{Author details}

${ }^{1}$ Institute of Hematology, Union Hospital, Tongji Medical College, Huazhong University of Science and Technology, 430022 Wuhan, China. ${ }^{2}$ Hubei Clinical Medical Center of Cell Therapy for Neoplastic Disease, 430022 Wuhan, China.

Received: 2 September 2021 Accepted: 12 December 2021

Published online: 24 January 2022

\section{References}

1. Auberger P, Tamburini-Bonnefoy J, Puissant A. Drug Resistance in Hematological Malignancies. Int J Mol Sci. 2020;21(17):6091.

2. Kershaw MH, Westwood JA, Darcy PK. Gene-engineered T cells for cancer therapy. Nat Rev Cancer. 2013;13(8):525-41.

3. Haslauer T, Greil R, Zaborsky N, Geisberger R. CART-cell therapy in hematological malignancies. Int J Mol Sci. 2021;22(16):8996.

4. Juluri KR, Wu V, Voutsinas JM, Hou J, Hirayama AV, Mullane E, et al. Severe cytokine release syndrome is associated with hematologic toxicity following CD19 CAR T-cell therapy. Blood Adv. 2021:bloodadvances.2020004142.

5. Xiang X, He Q, Ou Y, Wang W, Wu Y. Efficacy and safety of CAR-modified $T$ cell therapy in patients with relapsed or refractory multiple myeloma: a meta-analysis of prospective clinical trials. Front Pharmacol. 2020;11:544754.

6. PRISMA checklist [http://www.prisma-statement.org/PRISMAStatement/ Checklist.aspx].

7. Murad MH, Sultan S, Haffar S, Bazerbachi F. Methodological quality and synthesis of case series and case reports. BMJ Evid Based Med. 2018;23(2):60-3.

8. Ying Z, He T, Wang $X$, Zheng W, Lin N, Tu M, et al. Parallel comparison of 4-1BB or CD28 co-stimulated CD19-targeted CAR-T cells for B cell nonHodgkin's lymphoma. Mol Ther-Oncol. 2019;15:60-8.

9. Yan Z-X, Li L, Wang W, OuYang B-S, Cheng S, Wang L, et al. Clinical efficacy and tumor microenvironment influence in a dose-escalation study of anti-CD19 chimeric antigen receptor T cells in refractory B-cell nonHodgkin's lymphoma. Clin Cancer Res. 2019;25(23):6995-7003.

10. Sang W, Shi M, Yang J, Cao J, Xu L, Yan D, et al. Phase II trial of co-administration of CD19- and CD20-targeted chimeric antigen receptor $T$ cells for relapsed and refractory diffuse large B cell lymphoma. Cancer Med. 2020;9(16):5827-38. 
11. Tong C, Zhang Y, Liu Y, Ji X, Zhang W, Guo Y, et al. Optimized tandem CD19/CD20 CAR-engineered T cells in refractory/relapsed B-cell lymphoma. Blood. 2020;136(14):1632-44.

12. Xu J, Chen LJ, Yang SS, Sun Y, Wu W, Liu YF, et al. Exploratory trial of a biepitopic CAR T-targeting B cell maturation antigen in relapsed/refractory multiple myeloma. Proc Natl Acad Sci U S A. 2019;116(19):9543-51.

13. Zhao WH, Liu J, Wang BY, Chen YX, Cao XM, Yang Y, et al. A phase 1, openlabel study of LCAR-B38M, a chimeric antigen receptor T cell therapy directed against $B$ cell maturation antigen, in patients with relapsed or refractory multiple myeloma. J Hematol Oncol. 2018;11(1):141.

14. Shah NN, Johnson BD, Schneider D, Zhu F, Szabo A, Keever-Taylor CA, et al. Bispecific anti-CD20, anti-CD19 CART cells for relapsed B cell malignancies: a phase 1 dose escalation and expansion trial. Nat Med. 2020;26(10):1569-75.

15. Wang Y, Li H, Song X, Qi K, Cheng H, Cao J, et al. Kinetics of immune reconstitution after anti-CD19 chimeric antigen receptor $T$ cell therapy in relapsed or refractory acute lymphoblastic leukemia patients. Int J Lab Hematol. 2021;43(2):250-8.

16. Fried S, Avigdor A, Bielorai B, Meir A, Besser MJ, Schachter J, et al. Early and late hematologic toxicity following CD19 CAR-T cells. Bone Marrow Transplant. 2019;54(10):1643-50.

17. An F, Wang H, Liu Z, Wu F, Zhang J, Tao Q, et al. Influence of patient characteristics on chimeric antigen receptor T cell therapy in B-cell acute lymphoblastic leukemia. Nat Commun. 2020;11(1):5928.

18. Ramos CA, Grover NS, Beaven AW, Lulla PD, Wu MF, Ivanova A, et al. AntiCD30 CAR-T cell therapy in relapsed and refractory Hodgkin lymphoma. J Clin Oncol. 2020;38(32):3794-804.

19. Raje N, Berdeja J, Lin Y, Siegel D, Jagannath S, Madduri D, et al. Anti-BCMA CAR T-cell therapy bb2121 in relapsed or refractory multiple myeloma. N Engl J Med. 2019;380(18):1726-37.

20. Abramson JS, Palomba ML, Gordon LI, Lunning MA, Wang M, Arnason J, et al. Lisocabtagene maraleucel for patients with relapsed or refractory large B-cell lymphomas (TRANSCEND NHL 001): a multicentre seamless design study. Lancet (London, England). 2020;396(10254):839-52.

21. Wang M, Munoz J, Goy A, Locke FL, Jacobson CA, Hill BT, et al. KTE-X19 CAR T-cell therapy in relapsed or refractory mantle-cell lymphoma. $\mathrm{N}$ Engl J Med. 2020;382(14):1331-42.

22. Cohen AD, Garfall AL, Stadtmauer EA, Melenhorst JJ, Lacey SF, Lancaster $E$, et al. B cell maturation antigen-specific CART cells are clinically active in multiple myeloma. J Clin Invest. 2019;129(6):2210-21.

23. Goto H, Makita S, Kato K, Tokushige K, Fujita T, Akashi K, et al. Efficacy and safety of tisagenlecleucel in Japanese adult patients with relapsed/refractory diffuse large B-cell lymphoma. Int J Clin Oncol. 2020;25(9):1736-43.

24. Schuster SJ, Bishop MR, Tam CS, Waller EK, Borchmann P, McGuirk JP, et al. Tisagenlecleucel in adult relapsed or refractory diffuse large B-cell lymphoma. N Engl J Med. 2019;380(1):45-56.

25. Ghorashian S, Kramer AM, Onuoha S, Wright G, Bartram J, Richardson R, et al. Enhanced CART cell expansion and prolonged persistence in pediatric patients with ALL treated with a low-affinity CD19 CAR. Nat Med. 2019;25(9):1408-14.

26. Maude SL, Laetsch TW, Buechner J, Rives S, Boyer M, Bittencourt $H$, et al. Tisagenlecleucel in children and young adults with B-cell lymphoblastic leukemia. N Engl J Med. 2018;378(5):439-48.

27. Strati P, Varma A, Adkins S, Nastoupil LJ, Westin J, Hagemeister FB, et al. Hematopoietic recovery and immune reconstitution after axicabtagene ciloleucel in patients with large B-cell lymphoma. Haematologica. 2021;106(10):2667-72.

28. Locke FL, Ghobadi A, Jacobson CA, Miklos DB, Lekakis LJ, Oluwole OO, et al. Long-term safety and activity of axicabtagene ciloleucel in refractory large B-cell lymphoma (ZUMA-1): a single-arm, multicentre, phase 1-2 trial. Lancet Oncol. 2019;20(1):31-42.

29. Fry TJ, Shah NN, Orentas RJ, Stetler-Stevenson M, Yuan CM, Ramakrishna $\mathrm{S}$, et al. CD22-targeted CAR T cells induce remission in B-ALL that is naive or resistant to CD19-targeted CAR immunotherapy. Nat Med. 2018;24(1):20-8.

30. Ali SA, Shi V, Maric I, Wang M, Stroncek DF, Rose JJ, et al. T cells expressing an anti-B-cell maturation antigen chimeric antigen receptor cause remissions of multiple myeloma. Blood. 2016;128(13):1688-700.

31. Enblad G, Karlsson H, Gammelgard G, Wenthe J, Lovgren T, Amini RM, et al. A phase I/Ila trial using CD19-targeted third-generation
CART cells for lymphoma and leukemia. Clin Cancer Res. 2018;24(24):6185-94.

32. Schuster SJ, Svoboda J, Chong EA, Nasta SD, Mato AR, Anak Ö, et al. Chimeric antigen receptor $T$ cells in refractory B-cell lymphomas. N Engl J Med. 2017:377(26):2545-54.

33. Gardner RA, Finney $O$, Annesley C, Brakke H, Summers C, Leger $\mathrm{K}$, et al. Intent-to-treat leukemia remission by CD19 CART cells of defined formulation and dose in children and young adults. Blood. 2017:129(25):3322-31.

34. Curran KJ, Margossian SP, Kernan NA, Silverman LB, Williams DA, Shukla N, et al. Toxicity and response after CD19-specific CAR T-cell therapy in pediatric/young adult relapsed/refractory B-ALL. Blood. 2019;134(26):2361-8.

35. Ramos CA, Rouce R, Robertson CS, Reyna A, Narala N, Vyas G, et al. In vivo fate and activity of second- versus third-generation CD19-specific CAR-T cells in B cell non-Hodgkin's lymphomas. Mol Ther. 2018;26(12):2727-37.

36. Zhang WY, Wang Y, Guo YL, Dai HR, Yang QM, Zhang YJ, et al. Treatment of CD20-directed chimeric antigen receptor-modified T cells in patients with relapsed or refractory B-cell non-Hodgkin lymphoma: an early phase Ila trial report. Signal Transduct Target Ther. 2016;1:16002.

37. Lee DW, Kochenderfer JN, Stetler-Stevenson M, Cui YK, Delbrook C, Feldman SA, et al. T cells expressing CD19 chimeric antigen receptors for acute lymphoblastic leukaemia in children and young adults: a phase 1 dose-escalation trial. Lancet. 2015;385(9967):517-28.

38. Geyer MB, Rivière I, Sénéchal B, Wang X, Wang Y, Purdon TJ, et al. Autologous CD19-targeted CART cells in patients with residual CLL following initial purine analog-based therapy. Mol Ther. 2018;26(8):1896-905.

39. Geyer MB, Rivière I, Sénéchal B, Wang X, Wang Y, Purdon TJ, et al. Safety and tolerability of conditioning chemotherapy followed by CD19-targeted CART cells for relapsed/refractory CLL. JCI insight. 2019;5(9):e122627.

40. Sesques P, Ferrant E, Safar V, Wallet F, Tordo J, Dhomps A, et al. Commercial anti-CD19 CART cell therapy for patients with relapsed/refractory aggressive B cell lymphoma in a European center. Am J Hematol. 2020;95(11):1324-33.

41. Wang N, Hu X, Cao W, Li C, Xiao Y, Cao Y, et al. Efficacy and safety of CAR19/22 T-cell cocktail therapy in patients with refractory/relapsed B-cell malignancies. Blood. 2020;135(1):17-27.

42. Zhou X, Tu S, Wang C, Huang R, Deng L, Song C, et al. Phase I trial of fourth-generation anti-CD19 chimeric antigen receptor $T$ cells against relapsed or refractory B cell non-Hodgkin lymphomas. Front Immunol. 2020;11:564099.

43. Wang J, Mou N, Yang Z, Li Q, Jiang Y, Meng J, et al. Efficacy and safety of humanized anti-CD19-CAR-T therapy following intensive lymphodepleting chemotherapy for refractory/relapsed B acute lymphoblastic leukaemia. Br J Haematol. 2020;191(2):212-22.

44. Yan Z, Cao J, Cheng H, Qiao J, Zhang H, Wang Y, et al. A combination of humanised anti-CD19 and anti-BCMA CART cells in patients with relapsed or refractory multiple myeloma: a single-arm, phase 2 trial. Lancet Haematol. 2019;6(10):e521-9.

45. Bao F, Hu K, Wan W, Tian L, Jing HM. Efficacy of anti-CD19 CAR-T cell therapy in 10 refractory recurrent B cell malignancies. Zhonghua Xue Ye Xue Za Zhi. 2018;39(6):454-9. Chinese.

46. Jain T, Knezevic A, Pennisi M, Chen Y, Ruiz JD, Purdon TJ, et al. Hematopoietic recovery in patients receiving chimeric antigen receptor T-cell therapy for hematologic malignancies. Blood Adv. 2020;4(15):3776-87.

47. Popat R, Zweegman S, Cavet J, Yong K, Lee L, Faulkner J, et al. Phase 1 first-in-human study of AUTO2, the first chimeric antigen receptor (CAR) T cell targeting april for patients with relapsed/refractory multiple myeloma (RRMM). Blood. 2019;134(Supplement 1):3112.

48. Usmani SZ, Madduri D, Berdeja JG, Singh I, Zudaire E, Yeh TM, et al. Treatment of relapsed/refractory multiple myeloma with JNJ-4528, a B-cell maturation antigen (BCMA)-directed chimeric antigen receptor (CAR)-T cell therapy: update of phase $1 \mathrm{~b}$ results from cartitude-1. HemaSphere. 2020:4(Supplement 1):417-8.

49. Mailankody S, Jakubowiak A, Htut M, Costa L, Lee K, Ganguly S, et al. Orvacabtagene autoleucel (Orva-cel), a B-cell maturation antigen-directed car t cell therapy for patients with relapsed/refractory multiple myeloma: update of the phase 1/2 evolve study. HemaSphere. 2020;4(Supplement 1):418.

50. Hu J, Yang T, Yang X, Xian N, Chen Y, Jiang P, et al. Repeat infusion of CD19-specific chimeric antigen receptor T-cell could improve the 
efficacy with consistent safety in relapsed/refractory diffuse large B-cell lymphoma. Blood. 2018;132(Supplement 1):5385.

51. Amrolia PJ, Wynn R, Hough R, Vora A, Bonney D, Veys P, et al. Simultaneous targeting of CD19 and CD22: phase I study of AUTO3, a Bicistronic chimeric antigen receptor (CAR) T-cell therapy, in pediatric patients with relapsed/refractory B-cell acute lymphoblastic leukemia (r/r B-ALL): Amelia study. Blood. 2018:132(Supplement 1):279.

52. Ardeshna K, Marzolini MAV, Osborne W, Al-Hajj M, Thomas S, Faulkner J, et al. Study of AUTO3, the first Bicistronic chimeric antigen receptor (CAR) targeting CD19 and CD22, followed by anti-PD1 consolidation in patients with relapsed/refractory $(r / r)$ diffuse large B cell lymphoma (DLBCL): Alexander study. Blood. 2018;132(Supplement 1):1679.

53. Yan L, Yan Z, Shang J, Shi X, Jin S, Kang L, et al. Sequential CD19-and Bcma-specific chimeric antigen receptor T cell treatment for RRMM: report from a single center study. Blood. 2019;134(Supplement_1):578.

54. Wierda WG, Bishop MR, Oluwole OO, Logan AC, Baer MR, Donnellan WB, et al. Updated phase 1 results of Zuma-3: Kte-C19, an anti-CD19 chimeric antigen receptor $\mathrm{T}$ cell therapy, in adult patients with relapsed/refractory acute lymphoblastic leukemia. Blood. 2018;132(Supplement 1):897.

55. Topp MS, Van Meerten T, Wermke M, Lugtenburg PJ, Minnema MC, Song KW, et al. Preliminary results of earlier steroid usewith axicabtagene ciloleucel (AXI-CEL) in patients with relapsed/refractory large b cell lymphoma. Hematol Oncol. 2019;37(Supplement 2):305.

56. Jiang $\mathrm{S}$, Jin J, Hao S, Yang M, Chen L, Ruan H, et al. Low dose of human sCFv-derived BCMA-targeted CAR-T cells achieved fast response and high complete remission in patients with relapsed/refractory multiple myeloma. Blood. 2018;132(Supplement 1):960.

57. Dourthe ME, Rabian F, Yakouben K, Cabannes A, Chevillon F, Chaillou $D$, et al. Safety and efficacy of tisagenlecleucel (CTLO19) in B-cell acute lymphoblastic leukemia in children, adolescents and young adults: the French experience. Blood. 2019;134(Supplement 1):3876.

58. Jacobson C, Chavez JC, Sehgal AR, William BM, Munoz J, Salles G, et al. Primary analysis of Zuma-5: a phase 2 study of Axicabtagene Ciloleucel (Axi-Cel) in patients with relapsed/refractory (R/R) indolent non-Hodgkin lymphoma (iNHL). Blood. 2020;136(Supplement 1):40-1.

59. Wayne AS, Huynh V, Hijiya N, Rouce R, Brown PA, Krueger J, et al. PS962 phase 1 results of ZUMA-4: KTE-X19, an anti-CD19 chimeric antigen receptor $t$ cell therapy, in pediatric and adolescent patients with relapsed/refractory b cell acute lymphoblastic leukemia. HemaSphere. 2019:3(S1):433.

60. Maude SL, Frey N, Shaw PA, Aplenc R, Barrett DM, Bunin NJ, et al. Chimeric antigen receptor T cells for sustained remissions in leukemia. N Engl J Med. 2014;371(16):1507-17.

61. Yan Z, Wang W, Zheng Z, Hao M, Yang S, Li J, et al. Efficacy and Safety of JWCARO29 in adult patients with relapsed and refractory B-cell nonHodgkin lymphoma. Blood. 2018;132(Supplement 1):4187.

62. Zhao X, Yang J, Zhang X, Lu X-A, Xiong M, Zhang J, et al. Efficacy and safety of CD28-or 4-1BB-based CD19 CAR-T cells in B cell acute lymphoblastic leukemia. Molecular Therapy-Oncolytics. 2020;18:272-81.

63. Zheng XH, Zhang XY, Dong QQ, Chen F, Yang SB, Li WB. Efficacy and safety of chimeric antigen receptor- $T$ cells in the treatment of $B$ cell lymphoma: a systematic review and meta-analysis. Chin Med J. 2020;133(1):74-85.

64. Mohyuddin GR, Rooney A, Balmaceda N, Aziz M, Sborov DW, McClune $B$, et al. Chimeric antigen receptor T-cell therapy in multiple myeloma: a systematic review and meta-analysis of 950 patients. Blood advances. 2021;5(4):1097-101.

65. Anagnostou T, Riaz IB, Hashmi SK, Murad MH, Kenderian SS. Anti-CD19 chimeric antigen receptor T-cell therapy in acute lymphocytic leukaemia: a systematic review and meta-analysis. The Lancet Haematology. 2020;7(11):e816-26.

66. Neelapu SS, Locke FL, Bartlett NL, Lekakis LJ, Miklos DB, Jacobson CA, et al. Axicabtagene Ciloleucel CART-cell therapy in refractory large B-cell lymphoma. N Engl J Med. 2017;377(26):2531-44.

67. Kochenderfer JN, Somerville RPT, Lu T, Yang JC, Sherry RM, Feldman SA, et al. Long-duration complete remissions of diffuse large B cell lymphoma after anti-CD19 chimeric antigen receptor T cell therapy. Mol Ther. 2017;25(10):2245-53.

68. Cordeiro A, Bezerra ED, Hirayama AV, Hill JA, Wu QV, Voutsinas J, et al. Late events after treatment with CD19-targeted chimeric antigen receptor modified T cells. Biology of Blood and Marrow Transplantation. 2020;26(1):26-33.

69. Cappell KM, Sherry RM, Yang JC, Goff SL, Vanasse DA, McIntyre L, et al. Long-term follow-up of anti-CD19 chimeric antigen receptor T-cell therapy. J Clin Oncol. 2020;38(32):3805-15.

70. Warrier VU, Makandar Al, Garg M, Sethi G, Kant R, Pal JK, et al. Engineering anti-cancer nanovaccine based on antigen cross-presentation. Biosci Rep. 2019;39(10):BSR20193220.

71. Buie LW. Balancing the CART: perspectives on efficacy and safety of CAR T-cell therapy in hematologic malignancies. Am J Manag Care. 2021;27(13 Suppl):S243-52.

72. Schubert ML, Schmitt M, Wang L, Ramos CA, Jordan K, Müller-Tidow C, et al. Side-effect management of chimeric antigen receptor (CAR) T-cell therapy. Ann Oncol. 2021;32(1):34-48.

73. Kirtonia A, Pandya G, Sethi G, Pandey AK, Das BC, Garg M. A comprehensive review of genetic alterations and molecular targeted therapies for the implementation of personalized medicine in acute myeloid leukemia. J Mol Med (Berl). 2020;98(8):1069-91.

74. Yáñez L, Alarcón A, Sánchez-Escamilla M, Perales MA. How I treat adverse effects of CAR-T cell therapy. ESMO Open. 2020;4(Suppl 4):e000746.

75. Gauthier J, Hirayama AV, Purushe J, Hay KA, Lymp J, Li DH, et al. Feasibility and efficacy of CD19-targeted CART cells with concurrent ibrutinib for CLL after ibrutinib failure. Blood. 2020;135(19):1650-60.

\section{Publisher's Note}

Springer Nature remains neutral with regard to jurisdictional claims in published maps and institutional affiliations.

Ready to submit your research? Choose BMC and benefit from:

- fast, convenient online submission

- thorough peer review by experienced researchers in your field

- rapid publication on acceptance

- support for research data, including large and complex data types

- gold Open Access which fosters wider collaboration and increased citations

- maximum visibility for your research: over $100 \mathrm{M}$ website views per year

At BMC, research is always in progress.

Learn more biomedcentral.com/submissions 